\title{
LOS DERECHOS POLÍTICOS DE LOS MIEMBROS DE LAS FUERZAS ARMADAS A LA LUZ DEL PRINCIPIO DE NEUTRALIDAD POLÍTICA
}

\author{
Ignacio Álvarez Rodríguez ${ }^{1}$
}

\begin{abstract}
Sumario: 1. InTROducción. 2. El RECONOCIMIENTO DE DERECHOS POLíticos A los MiEMBros de LAS FuERZAS ARMADAS. 3. LA REGULACIÓN LEGAL DE LOS DERECHOS POLÍTICOS DE LOS MIEMBROS DE LAS FUERZAS Armadas. 3.1. El antecedente del antecedente: el Real Decreto-ley 10/1977, de 8 de febrero, por el que se regula el ejercicio de actividades politicas y sindicales por parte de los componentes de las Fuerzas Armadas. 3.2. El antecedente inmediato: la Ley 65/1978, de 28 de diciembre, de Reales Ordenanzas de las Fuerzas Armadas. 3.3. El marco jurídico actual: La Ley Orgánica 9/2011, de 27 de julio, de derechos y deberes de los miembros de las Fuerzas Armadas. 4. LA JURISPRUDENCIA CONSTITUCIONAL RELATIVA A LOS DERECHOS POLÍTICOS DE LOS MIEMBRos DE LAS FuERZAS ARMADAS. 4.1. Jurisprudencia constitucional sobre libertad de expresión. 4.2. Jurisprudencia constitucional sobre libertad de asociación. 5. EL PRINCIPIO DE NEUTRALIDAD POLÍTICA COMO LÍMITE A LOS DERECHOS POLÍTICOS DE LOS MIEMBROS DE LAS FUERZAS ARMADAS. 5.1. El deber de neutralidad politica como una realidad en el Derecho Comparado. 5.2. El deber de neu-
\end{abstract}

${ }^{1}$ El autor de estas líneas desea agradecer la inestimable ayuda que ha tenido para elaborar el presente artículo, tanto desde el ámbito civil como desde el militar. Vaya desde aquí, por ello, un sincero agradecimiento a D. Ignacio Torres Muro, Catedrático de Derecho Constitucional de la Universidad Complutense de Madrid y Letrado en excedencia del Tribunal Constitucional; a D. Luis Gálvez Muñoz, Profesor Titular de Derecho Constitucional de la Universidad de Murcia; a D. Andrés Dolón Payán, Coronel del Cuerpo General del Ejército del Aire; y a D. Tomás Buades González, Teniente Coronel del Cuerpo Jurídico Militar. El agradecimiento es extensible al personal de la Biblioteca de la Facultad de Derecho de la Universidad de Murcia, así como al personal civil y militar de la Biblioteca de la Academia General del Aire de San Javier. Huelga decir que todas las reflexiones, errores y omisiones que contiene el presente texto son de exclusiva responsabilidad del arriba firmante. 
tralidad política como límite permitido por la legislación internacional. 5.3. El deber de neutralidad política como una exigencia derivada de las funciones atribuidas a las Fuerzas Armadas. 6. CONCLUSIón.

\section{INTRODUCCIÓN}

El objetivo de las siguientes líneas es estudiar algunos aspectos del régimen jurídico de los derechos políticos de nuestros militares. Es sabido que en fechas no lejanas entró en vigor la Ley Orgánica 9/2011, de 27 de julio, de Derechos y Deberes de los Miembros de las Fuerzas Armadas, norma que trajo una nueva regulación que, a tenor de su contenido y tal y como se pretende exponer más adelante, no se antoja especialmente novedosa. La misma ha reglado los derechos políticos de los militares españoles al calor de un postulado -el principio de neutralidad política- que ha atravesado todos y cada uno de ellos, con las consiguientes restricciones en su ejercicio.

Para llevar a cabo tal cometido se repasará cómo se ha venido regulando la cuestión en nuestro país, así como el juicio que algunos aspectos de la misma han merecido al Tribunal Constitucional; posteriormente se harán algunas consideraciones sobre dicho régimen, centradas a su vez en cuestiones relacionadas con el Derecho Comparado, con el Derecho Internacional -especialmente con el Convenio Europeo de Derechos Humanos y la jurisprudencia del Tribunal Europeo de Derechos Humanos- así como con las exigencias que plantea el principio arriba aludido desde una óptica puramente interna ${ }^{2}$.

\section{EL RECONOCIMIENTO DE DERECHOS POLÍTICOS A LOS MIEMBROS DE LAS FUERZAS ARMADAS}

No parece que desde el constitucionalismo democrático moderno sea objeto de debate el hecho de que todos los ciudadanos -incluso los extranjeros en buena parte de ordenamientos- sean titulares de los derechos individuales más elementales. Estos, que suelen llamarse derechos fundamentales, responden a una idea estructural como es la dignidad humana, que actúa de base inexcusable para su reconocimiento ${ }^{3}$.

${ }^{2}$ A partir de ahora se emplearán las siguientes abreviaturas. Constitución Española, CE; Tribunal Constitucional; TC; Ley Orgánica 5/2005, de 17 de noviembre, de la Defensa Nacional, LODN. Ley Orgánica 2/1979, de 3 de octubre, del Tribunal Constitucional, LOTC; Sentencia del Tribunal Constitucional, STC; Sentencias del Tribunal Constitucional, SSTC; Fundamento Jurídico, FJ; Fundamentos Jurídicos, FFJJ; Convenio Europeo de Derechos Humanos, CEDH; Tribunal Europeo de Derechos Humanos, TEDH; STEDH, Sentencia del Tribunal Europeo de Derechos Humanos; Ley Orgánica 9/2011, de 27 de julio, de Derechos y Deberes de los Militares, LODDMFAS; Fuerzas Armadas Españolas, FAS.

3 Desde una perspectiva general, véase Gutiérrez Gutiérrez, I., Dignidad de la Persona y Derechos Fundamentales, Marcial Pons, Madrid-Barcelona, 2005; y OeHLing 
Nuestra Constitución de 1978 se inserta en dicha tradición (ex artículo 10 $\mathrm{CE})^{4}$, garantizando de forma amplia un conjunto de derechos fundamentales dentro de los cuales quedan incluidos los derechos políticos; derechos todos ellos íntimamente unidos a la propia esencia de la democracia ${ }^{5}$. En lo que hace a los segundos se alude a, cuanto menos, el derecho a la libre expresión (artículo $20 \mathrm{CE}$ ), a la libre participación política (derechos de sufragio activo y pasivo, artículo $23 \mathrm{CE}$; y derecho de petición, artículo $29 \mathrm{CE}$ ), a la libre reunión y manifestación (artículo $21 \mathrm{CE}$ ), y a la libre asociación (artículo $22 \mathrm{CE}$ ).

No obstante, el ejercicio de alguno de estos derechos aparece ya limitado en la Norma suprema para ciertas categorías de ciudadanos. Es, sin duda, el caso de los militares, quienes tienen restringidos ex constitutione el derecho de sufragio pasivo y el derecho de petición ${ }^{6}$. Fuera de tales supuestos, aquélla no establece ulteriores límites a los derechos políticos de los militares, por lo que el legislador, respetando las exigencias constitucionales propias, podría haberlos reconocido sin cortapisas. Se puede ya adelantar que eso no ha sido así históricamente; tampoco es el caso de la reciente regulación que de los mismos hizo la LODDMFAS.

Explicaciones doctrinales a esta tendencia se han dado varias, aunque todas ellas pueden incardinarse en torno a dos grandes ramas. Por un lado se ha hablado, y mucho, sobre la noción del ciudadano en uniforme, visión que privilegia un modelo de soldado que se implique en la vida política de su país, con pocas (pero necesarias) limitaciones ${ }^{7}$. Por otro lado destaca la que defien-

DE los Reyes, A., La Dignidad de la Persona, Dykinson, Madrid, 2010. Desde el ámbito militar, véase MARTín RETORTILLO, L., «Algunas reflexiones sobre la situación jurídica del soldado», en RAmírez JimÉnEZ, M. (ed.); López RAMÓN, F. (dir.); FERnÁNDEZ LóPEZ, J. (coord.), La Función Militar en el Actual Ordenamiento Constitucional Español, Trotta, Madrid, 1995, pp. 227 y ss.

${ }^{4}$ Vid. DíEz Picazo, L.M. ${ }^{\text {a }}$, Sistema de Derechos Fundamentales, Thomson-Civitas, Cizur Menor, 2008 ( $2^{\mathrm{a}}$ edición), pp. 70 y ss.

5 Según Ferrajoli, lo que caracterizaría a una democracia auténtica a día de hoy, además de la participación del pueblo en los asuntos políticos, es el reconocimiento y garantía de tales derechos. Vid. Ferrajoli, L., Poderes salvajes. La crisis de la democracia constitucional. Trotta, Madrid, 2011, pássim.

${ }^{6}$ El primero aparece limitado en el artículo 70 1. e) CE, donde se dirá que: «La ley electoral determinará las causas de inelegibilidad e incompatibilidad de los Diputados y Senadores, que comprenderán, en todo caso: (...) A los militares profesionales (...) en activo». El segundo se limita en el artículo 29.2 CE, precepto que reza así: «Los miembros de las Fuerzas o Institutos armados o de los Cuerpos sometidos a disciplina militar podrán ejercer este derecho sólo individualmente y con arreglo a lo dispuesto en su legislación específica».

7 La noción del ciudadano en uniforme, proveniente de Alemania, considera que el aislamiento al que quedaban sometidos los soldados no consiguió integrarlos en el sistema, al que veían ajeno y extraño. Aun con las cautelas propias que impone la complejidad del caso alemán, parece que esa pudo ser una de las razones que condujo a que las Fuerzas Armadas alemanas fueran contra el modelo weimariano. Vid. STEIN, T., «Rol de las Fuer- 
de que la relación del militar profesional es una relación de sujeción especial, de la que derivan especiales cargas y deberes para el empleado ${ }^{8}$. Aunque esta noción dista de concitar la unanimidad doctrinal, lo que todos parecen aceptar es que nos encontramos ante funcionarios públicos cualificados que requieren, por mor de su profesión y las exigencias que esta plantea, una regulación jurídica específica ${ }^{9}$. Lo que lleva a otra cuestión no menos interesante y que también irradia su fuerza en la materia; se habla de la doctrina de los límites de los límites de los derechos fundamentales, un conjunto de técnicas jurídicas que velan por adecuar las eventuales restricciones que se impongan al ejercicio de tales derechos ${ }^{10}$. Doctrina que también se ha dejado sentir y que obliga al legislador a ser especialmente cuidadoso a la hora de regularlos ${ }^{11}$.

\section{LA REGULACIÓN LEGAL DE LOS DERECHOS POLÍTICOS DE LOS MIEMBROS DE LAS FUERZAS ARMADAS}

Si se hace un repaso sosegado por nuestra Historia, se podrá observar cómo la relación entre política y Ejército no ha sido fácil ${ }^{12}$. Y no ha sido fácil

zas Armadas en el Orden Constitucional de Alemania», Ius et Praxis, vol. 8, núm. 1, 2002, pp. 1-10; y Laguna SAnquirico, F., «El Militar, Ciudadano de Uniforme (Deberes y derechos del soldado)», Revista de Estudios Políticos, núm. 56, 1987, pp. 121-135.

${ }^{8}$ Desde la idiosincrasia de cada Estado, esta es la opción prevalente en Francia y en Italia. La noción ha tenido cierta recepción en España a nivel normativo, jurisprudencial y doctrinal. Vid. Gómez Martínez, R., Derechos Fundamentales y Condición Militar, Thomson-Reuters, Cizur Menor, 2010, p. 91 y ss; Pascua Mateo, F., Fuerzas Armadas y Derechos Politicos, Congreso de los Diputados, Madrid, 2006, p. 73 y ss; y PeÑARruBIA IzA, J.M. ${ }^{\text {, }}$ Presupuestos Constitucionales de la Función Militar, CEPC, Madrid, 2000, p. 89 y ss.

9 No obstante, hay que señalar que esta categoría jurídica ha sido ampliamente discutida, sobre todo por su objetivo primigenio, cual era que la Administración sorteara cualquier control parlamentario, fuera directo o indirecto. Vid. GARCíA MACHO, R., Las Relaciones de Especial Sujeción en la Constitución Española, Tecnos, Madrid, 1982; y LóPEZ Benítez, M., Naturaleza y presupuestos constitucionales de las relaciones especiales de sujeción, Civitas, Madrid, 1994; recientemente, véase Prieto Álvarez, T., «La encrucijada de las relaciones especiales de sujeción», Revista de Administración Pública, núm. 178, 2009, pp. 215-247.

${ }^{10}$ Por todos, véase Presno Linera, M.A., «Los límites de los límites a los derechos fundamentales de los militares», Boletín de Información, núm. 278, 2003, pp. 69-96.

${ }_{11}$ Destacando el principio de favor libertatis, donde «la libertad es el principio y la limitación la excepción». Vid. MARTín RetORTILlo, L., «Algunas reflexiones sobre la situación jurídica del soldado», op. cit., p. 231.

12 Sobre esta cuestión puede verse Puell De La Villa, F., Historia del Ejército en España, Alianza Editorial, Madrid, 2005; y BARCELONA LLOP, J., «Profesionalismo, militarismo e ideología militar», Revista de Estudios Políticos, núm. 51, 1986, pp. 127-161. En lo que hace a España, al acabar la Guerra Civil se dio especial pábulo a un conjunto de teorías que, de una u otra forma, insistían en la figura del Ejército redentor, Ejército que no sólo tenía como deber inexcusable salvar a la sociedad, sino ser la fuerza política que 
quizá porque ha sido demasiado intensa, siendo muchas las veces que las FAS decidieron intervenir políticamente ante el cariz que tomaban unos acontecimientos cuyo devenir deseaban, cuanto menos, corregir ${ }^{13}$.

A lo mejor por eso, y entre otras razones, cuando nuestro país se enfrentó a su momento transicional, se quiso privilegiar una absoluta neutralidad política de los miembros de las FAS respecto al proceso que vendría a nacer ${ }^{14}$. Ese

mantuviera las esencias estatales, conservara el orden interno y, en suma, controlara al poder civil. Uno de los precursores de esta visión fue OeHLIng, H., La Función Política del Ejército, IEP, Madrid, 1967. En sentido muy similar, véase GARCíA ARIAS, L., «Las Fuerzas Armadas en la Ley Orgánica del Estado», Revista de Estudios Políticos, núm. 152, 1967, pp. 137-156. Sobre estos debates puede verse LóPEz RAmón, F., La Caracterización Jurídica de las Fuerzas Armadas, Centro de Estudios Constitucionales, Madrid, 1987, p. 216 y ss; y Cotino Hueso, L., El Modelo Constitucional de Fuerzas Armadas, CEPC, Madrid, 2002, pp. 351 y ss.

${ }^{13}$ La Historia de España está jalonada de intervenciones militares en política, desde las presiones verbales más sutiles y difusas hasta los cruentos Golpes de Estado. Un estudio en profundidad de estos avatares puede verse en FERnÁndEZ LóPEZ, J., Militares contra el Estado, Taurus, Madrid, 2003. Un ejemplo de esto también sería el de la Unión Militar Democrática (UMD), organización necesariamente clandestina que actuó entre 1974 y 1977 con el objetivo de derrocar al franquismo mediante la reivindicación democrática. Los diversos documentos fundacionales así lo acreditan. Por ejemplo el Ideario, donde se explicitan diferentes «Objetivos Nacionales» tales como «(...) el restablecimiento pleno de los Derechos del Hombre y de las libertades democráticas»; realizar las «(...) reformas de tipo socioeconómico conducentes a igualar la distribución de la riqueza (...)»; el «reconocimiento en todos los organismos territoriales e institucionales del derecho a elegir democráticamente a sus autoridades y darles la forma de gobierno y organización que juzguen más adecuada (...)»; «(...) combatir con la máxima energía la corrupción, propiciada por el Régimen $(. .)$.$» ; y «(...) la convocatoria de una Asamblea$ Constituyente elegida democráticamente (...)». El documento, así como el resto de escritos que legó la Unión, pueden verse en la tesis doctoral elaborada por GómEz RosA, F., La Unión Militar Democrática en la Transición Política, UCM, Madrid, 2007, pp. 599 y ss (el texto se ha leído aquí: <http://www.eprints.ucm.es/7700/1/T29997.pdf>, el 18 de junio de 2014). El mismo autor ha publicado una versión reciente de la misma. Véase Los militares olvidados por la democracia, vive Libro, Madrid, 2013. Sobre el tema puede verse, entre otros, BusqueTs, J., Militares y Demócratas, Plaza\&Janés, Barcelona, 1999; y FERNÁNDEZ LóPEZ, J., UMD: Militares contra Franco. Historia de la Unión Militar Democrática, Mira Editores, Zaragoza, 2002.

${ }^{14}$ Lo cierto es que ese periodo se caracterizó por las concesiones mutuas. En el caso de los Ejércitos estas, vistas con la perspectiva que da el paso del tiempo, no fueron pocas. A lo largo del régimen franquista aquéllos habían participado activamente en la gobernanza del Estado desde diferentes altos órganos, cargos y puestos de la Administración (civil y militar), hasta el punto de que algún autor los consideraba la «cantera política» del franquismo. A ello debe sumarse que el estamento castrense aceptaba con suma naturalidad el hecho de que las Fuerzas Armadas no quedasen sujetas a un principio que a día de hoy está fuera de discusión, como es su pleno sometimiento a la autoridad civil. Vid BusQUETS, J., El Militar de Carrera en España, Ariel, Barcelona, 1984; BAÑón MARTínEz, R., y OLMEDA GómEZ, J., «Las Fuerzas Armadas en España: Institucionalziación y Proceso de 
deseo de mantener la neutralidad política se ha hecho mediante diferentes medios normativos, manteniéndose en el tiempo hasta llegar a nuestros días.

\subsection{El antecedente del antecedente: el Real Decreto-ley 10/1977, de 8 de febrero, por el que se regula el ejercicio de actividades políticas y sindicales por parte de los componentes de las Fuerzas Armadas}

Hija de su tiempo en todos los sentidos, esta norma con rango legal podría ser un buen reflejo de lo que se dijo más arriba. La restricción de los derechos políticos de los militares era, con la misma en la mano, casi absoluta ${ }^{15}$. Desde una concepción marcadamente tutelar -el Ejército como garante del sistema político en su conjunto- el Preámbulo de la norma no dejaba lugar a dudas ${ }^{16}$. El artículo primero ejecutaba tales dictados, optando directamente por prohibir todo ejercicio de actividades políticas $\mathrm{y} / \mathrm{o}$ sindicales dentro de cualquier dependencia militar ${ }^{17}$. A mayor abundamiento, en el artículo segundo se

Cambio», en Bañón Martínez, R., y Olmeda Gómez, J., La Institución Militar en el Estado Contemporáneo, Alianza Editorial, Madrid, 1985, pp. 270-325; y OLMEDA GóMEZ, J.A., Las Fuerzas Armadas en el Estado Franquista, Ediciones El Arquero, Madrid, 1988; recientemente, Martín Villa, R., «Claves de la Transición», Discurso de Recepción en la Real Academia de Ciencias Morales y Políticas, 26 de noviembre de 2013 (el texto se ha leído aquí: <http://www.racmyp.es/docs/discursos/D86.pdf>, el 22 de mayo de 2014); y AzNAR FernándeZ-Montesinos, F., «Militares en la España de hoy», Claves de Razón Práctica, núm. 229, 2013, p. 8 y ss.

15 Vid. Casado Burbano, P., «La Despolitización de los Militares Profesionales en la España Democrática», en BAÑón MARTínez, R. y OlmedA GómEZ, J., Fuerzas Armadas y Sociedad, II Jornadas de Sociología de la Asociación Castellana de Sociología, Madrid, 1983 , p. 12 y ss.

16 «(...) Son, pues, las Fuerzas Armadas una Institución sustantiva fundamental en el orden de la sociedad, cimiento y garantía del Estado, de su supervivencia y de su vida, es decir, del orden institucional y de la actividad política. La naturaleza de su misión está más allá de las opciones políticas concretas. Las Fuerzas Armadas están directa y entrañablemente unidas al pueblo, del que nacen, y a sus instituciones fundamentales y son depositarias de su confianza y seguridad, polarizando su atención en la custodia de lo que es consustancial con la existencia misma de la Patria. Las Fuerzas Armadas no son, pues, ajenas a la política en su más fundamental acepción, es decir, a aquellas actividades orientadas a defender un orden que asegure el interés general de la Nación. Por ello, serenamente conscientes de su capacidad política potencial, las Fuerzas Armadas y sus miembros tienen el deber de mantenerse unidos para el mejor cumplimiento de su elevada misión cuando sus obligaciones constitucionales así lo exijan. Este deber impone a todos los componentes de las Fuerzas Armadas el debido respeto a cualquier opción política de las que tienen cabida en el orden institucional, sin que les sea lícito, en consecuencia, participar ni mostrar públicamente su preferencia por cualquiera de ellas (...)».

17 «Quedan prohibidas las actividades políticas o sindicales dentro de los recintos, establecimientos, buques y aeronaves de las Fuerzas Armadas». 
concretaba qué derechos acrecían a los militares, quedando sólo salvada la posibilidad de ejercer el derecho de sufragio activo ${ }^{18}$. El resto de libertades a las que hemos hecho referencia más arriba -y otras- sólo podrían ser ejercidas, con carácter general y siguiendo el artículo quinto, si se solicitaba y obtenía el pase a la situación de retirado ${ }^{19}$. Dicho con otras palabras: en la práctica, pesaba mucho el uniforme y muy poco la condición de ciudadano.

Una voz autorizada en la materia, el Teniente General y Vicepresidente primero del Gobierno para Asuntos de la Defensa D. Manuel Gutiérrez Mellado, razonó algunos pormenores de dicha ordenación. La idea que subyacía a la misma, según dijo, era intentar consolidar a los Ejércitos como un bloque que «ha de ser invulnerable a cualquier intento de desunión». A su vez, no negaba la posibilidad de que cualquier soldado pudiera tener sus propias ideas («aisladamente»), pero el hecho de pertenecer a la institución exigía sacrificios especiales. Dicho con sus palabras: «(...) mientras llevemos nuestro uniforme e invoquemos nuestra condición de militar, debemos olvidarnos de toda causa política partidista, tanto en nuestros cuarteles, bases aéreas, arsenales y buques, como en nuestras reuniones y manifestaciones públicas -orales o escritas- sin que nos sea lícito afiliarnos, colaborar o prestar apoyo a ningún tipo de organización política o sindical, salvo el derecho a emitir nuestro voto electoral» ${ }^{20}$.

18 «Quienes con carácter profesional formen parte de las Fuerzas Armadas, cualquiera que sea su empleo y situación, no podrán, salvo lo establecido en el artículo quinto: Uno. Estar afiliados, colaborar o prestar apoyo a ningún tipo de organización política o sindical, salvo el derecho de sufragio activo. Dos. Expresar públicamente, en cualquier forma, opiniones de carácter político o sindical, en relación con las distintas opciones de partido, grupo, asociación u organización. Tres. Asistir a reuniones públicas de carácter político o sindical organizadas o promovidas por partidos, grupos o asociaciones de igual carácter. Asistir de uniforme o haciendo uso de su condición de militar a cualesquiera otras reuniones públicas de carácter político o sindical. Cuatro. Ejercer cargos públicos o aceptar candidaturas para los mismos cuando sean electivos y tengan carácter político o sindical. Cinco. Aceptar y ejercer cargos públicos de designación directa, salvo los de la administración militar o que sean propios de su condición militar y los que se determinan en el artículo tercero».

19 «Para poder ejercer las actividades que se mencionan en el artículo segundo, el personal al que el mismo se refiere deberá: Uno. Solicitar y obtener el pase a la situación de «retirado», con los derechos pasivos y asistenciales que le correspondan, si se trata de Jefes, Oficiales, Suboficiales y clases profesionales. Dos. Solicitar y obtener, si se trata de Oficiales Generales, el pase definitivo a «situación especial» que, con el exclusivo fin de posibilitarles el ejercicio de las mencionadas actividades, se crea por el presente Real Decreto-ley. - Los que voluntariamente se acogieran a esta «situación especial», a la que se puede acceder desde cualquier otra de las existentes en el generalato, tendrán los mismos derechos económicos y asistenciales que pudieran corresponderle en la situación de reserva. - A los demás efectos, incluso los jurisdiccionales, la «situación especial» queda equiparada a la de «retirado». Tres. No hacer uso del uniforme ni hacer valer su condición o jerarquía militar en el ejercicio de aquellas actividades».

${ }^{20}$ Gutiérrez Mellado, M., «Líneas maestras de la política militar», Discurso pronunciado en la Capitanía General de Sevilla, 7 de febrero de 1977. El texto puede consul- 
Por lo demás, tampoco cabe eludir el momento histórico que encerraba el otro momento histórico: se iban a celebrar las primeras elecciones libres y verdaderamente democráticas después de casi cuarenta años. Con ello se quiere decir que esta norma, a priori muy poco adecuada a los derechos fundamentales que la Constitución vino a reconocer de forma sumamente generosa muy poco tiempo después, cumplió una importante función para el conjunto del pueblo español: garantizar la posibilidad de que ejerciera en libertad su derecho a elegir los representantes que estimase oportuno, sin interferencias de ningún sector; especialmente las que pudieran provenir del estamento militar ${ }^{21}$.

\subsection{El antecedente inmediato: la Ley 65/1978, de 28 de diciembre, de Reales Ordenanzas de las Fuerzas Armadas}

Andando bien poco en el tiempo, se promulgaron las Reales Ordenanzas de las Fuerzas Armadas, con el revestimiento de rango legal ordinario ${ }^{22}$. En

tarse aquí: <http://e-spacio.uned.es/fez/eserv.php?pid=bibliuned:IUGM-DocGGM$19770202 \& d s I D=$ Transcripcion_del_documento.pdf>. Leído el 4 de mayo de 2014.

${ }^{21}$ Es sabido que existen en nuestro país voces que sostienen que el proceso transicional en España estuvo vigilado muy de cerca por el Ejército. Vid. CAPELLA, J-R., «La Constitución tácita», en CAPella, J-R. (ed.), Las Sombras del Sistema Constitucional Español, Trotta, Madrid, 2003, p. 33 y ss. Pero la realidad más o menos actual del sistema político español no resiste dicha afirmación a juicio de otros expertos, para quienes «(...) nuestra democracia no es una democracia gobernada ni, menos aún, vigilada, es una democracia gobernante y abierta (...)». Vid. HERRERo DE MiÑón, M., «Sobre el artículo 8 de la Constitución», El País, 23 de enero de 2006. Recientes testimonios atestiguan, no obstante, que estas cuestiones son algo más complejas de lo que a priori pueda pensarse. Así, el que fuera Presidente del Gobierno, D. José Luis Rodríguez Zapatero, parecía mostrar cierta sorpresa cuando se le interrogaba sobre «si las Fuerzas Armadas habían aceptado de buen grado la orden del Gobierno de retirarse de Irak». Mostrándose seguro de que la pregunta «no se hubiera trasladado a ninguno de los ejecutivos de los países de nuestro entorno», el ex Presidente defendía que «era 2004 y [nuestras Fuerzas Armadas] habían acreditado su profesionalidad en la defensa de los principios constitucionales desde hacía mucho tiempo, pero aún pesaba la histórica cuestión militar de nuestro país». Estas aseveraciones pueden verse en RODRÍGUEZ ZAPATERO, J.L., «Irak y la fuerza de la democracia», El Mundo, 21 de abril de 2014 (el artículo se ha leído aquí: <http://www.elmundo.es/opin ion/2014/04/20/535415bfca4741d56d8b4575.html>. Acceso: 2 de mayo de 2014). Sea como fuere, de lo que caben pocas dudas es de que la CE puso las bases para solucionar el llamado «el problema militar». Vid. SuÁrez Pertierra, G., "Veinticinco Años de Constitución y Fuerzas Armadas», Revista de Derecho Político, no 58-59, 2003-2004, p. 97 y ss; y Pérez Villalobos, Ma .C., «La Configuración Constitucional de las Fuerzas Armadas», Revista Española de Derecho Militar, no 78, 2001, p. 145 y ss.

${ }^{22}$ El origen de las Reales Ordenanzas data de 1768, año en el que fueron publicadas bajo el reinado de Carlos III. Su principal razón de ser era codificar y sistematizar el régimen del personal militar en sus diferentes aspectos, haciendo especial hincapié en los 
ellas también se hizo una regulación individual de cada uno de los derechos referidos más arriba. La tónica general que planea sobre esta no es muy diferente de la que se ha explicitado líneas atrás: un significativo recelo a que el militar se convierta en un sujeto políticamente vivo y dinámico, más allá de que pueda ejercer, si así lo desea, el derecho al sufragio activo.

Es así como se deja para el final de la norma la regulación de los deberes y derechos de los militares (Tratado Tercero, Título V). Y dicha regulación comienza por recordar algo que casaría, peor o mejor, con lo que se dijo arriba: el militar es titular de derechos fundamentales (también políticos), pero verá seriamente restringido su ejercicio por exigencias derivadas de la profesión militar ${ }^{23}$. La restricción operaba a través de dos grandes mecanismos. De un lado, la imposición de límites severos a la hora de regular el marco de cada derecho individualmente considerado. De otro, reforzando el principio de neutralidad política, postulado que como luego se verá también tiene una relevante cuota de protagonismo en la actualidad.

Respecto a los primeros, destaca en primer término la libertad de expresión, libertad que quedaba sometida al régimen de autorización previa a la hora de ejercerla, en aras de proteger la seguridad nacional, así como para prevenir la utilización incorrecta de datos que sólo por razón del cargo y/o destino se hubieren conocido ${ }^{24}$. La libertad de reunión se restringe intensamente en lo que hace a una de sus principales expresiones, como es el derecho a manifestarse ${ }^{25}$. Por lo demás, aquellas reuniones que quisieran celebrarse dentro de dependencias militares debían contar con la autorización expresa de su jefe. Con todo y con eso, la norma no permitía que el militar participase, interna o externamente, en algunas modalidades de reunión que podríamos

principios éticos por los que debía regirse todo sujeto que integrase la carrera de las armas. Para profundizar en tales aspectos véase la «Introducción Histórica» que figura en las Reales Ordenanzas para las Fuerzas Armadas, Talleres del Servicio Geográfico del Ejército, Madrid, 1979, pp. 9-15. La fuerza de la tradición y la más que probable utilidad de las mismas a la hora de vertebrar el factor humano dentro de las FAS ha conducido a que estas sigan vigentes, ahora con rango reglamentario y recogiendo las evoluciones propias en la materia, en el Real Decreto 96/2009, de 6 de febrero, por el que se aprueban las Reales Ordenanzas para las Fuerzas Armadas.

${ }^{23}$ Artículo 169: «El militar tiene los derechos civiles y políticos reconocidos en la Constitución, sin otras limitaciones que las impuestas por ella, por las disposiciones que la desarrollen y por estas Ordenanzas»».

${ }^{24}$ Artículo 178: «El militar tiene derecho a la libertad de expresión, pero necesitará autorización previa para su ejercicio cuando trate cuestiones que pudieran perjudicar a la debida protección de la seguridad nacional o utilice datos que sólo pueda conocer por razón de su destino o cargo en las Fuerzas Armadas».

${ }^{25}$ Conviene tener presente que el derecho de reunión constitucionalmente reconocido sólo engloba un derecho -el de reunirse- que puede ejercitarse de forma estática (concentración, reunión) y/o de forma dinámica (manifestación propiamente dicha). Vid. DíEz PicAzo, L.M. ${ }^{\text {, }, ~ S i s t e m a ~ d e ~ D e r e c h o s ~ F u n d a m e n t a l e s, ~ o p . ~ c i t ., ~ p . ~} 389$ y ss. 
denominar «sospechosas» ${ }^{26}$. Otro tanto podría decirse de la libertad de asociación, cuya directriz obedecía al espíritu comentado: se permite que participen en asociaciones en tanto en cuanto dichas asociaciones no tengan carácter sindical y/o «reivindicativo» ${ }^{27}$. En el otro lado de la balanza, se les reconocía sin ulteriores restricciones el derecho de sufragio activo ${ }^{28} ; \mathrm{y}$, como también venía siendo norma, el derecho de petición quedaba limitado al ejercicio individual del mismo, siguiendo las formalidades dictadas por aquélla ${ }^{29}$.

Respecto al segundo, creemos que la neutralidad política fue asegurada tanto directa como indirectamente. Es así como, partiendo de la base de que el militar debía respetar toda opción política legítima desde el punto de vista constitucional, se exigía del mismo un riguroso apartamiento de cualquier actividad de índole política ${ }^{30}$. Indirectamente, las Reales Ordenanzas también seguían preocupadas porque lo político no contaminase el desempeño de la

${ }^{26}$ Artículo 180: «Los militares podrán reunirse libremente para fines lícitos, en lugares públicos o privados, observando lo que, con carácter general o específico establezcan las disposiciones vigentes. En las unidades, buques y dependencias será imprescindible la autorización expresa de su jefe. En ningún caso podrán tomar parte en manifestaciones de tipo político, sindical o reivindicativo». Según algunos expertos, el tratamiento normativo era el correcto. Por decirlo con las palabras de uno de ellos, «(...) Si se quiere mantener la neutralidad de las Fuerzas Armadas, la asistencia de uniforme de los militares a las manifestaciones o reuniones de tipo político no parece precisamente una práctica que contribuya a reforzar la imagen de un Ejército al servicio de todos (...)». Vid. Torres Muro, I., El Derecho de Reunión y Manifestación, Civitas, Madrid, 1991, pp. 69 y 70.

27 Artículo 181: «Los miembros de las Fuerzas Armadas, por cuyos intereses vela el Estado, no podrán participar en sindicatos y asociaciones con finalidad reivindicativa. Tampoco podrán condicionar, en ningún caso, el cumplimiento de sus cometidos a una mejor satisfacción de sus intereses personales o profesionales ni recurrir a ninguna de las formas directas o indirectas de huelga. Los militares podrán pertenecer a otras asociaciones legalmente autorizadas de carácter religioso, cultural, deportivo o social».

28 Artículo 184: «Los mandos militares darán las debidas facilidades a los componentes de las Fuerzas Armadas para que puedan ejercer libremente su derecho a voto».

29 Artículo 203: «Cualquier militar podrá dirigir propuestas a sus superiores haciéndolo individualmente y por conducto regular. Cuando sea autorizado para ello podrá recabar el parecer de sus compañeros para la consideración de posibles sugerencias, que habrán de ser presentadas por el más caracterizado. No se podrá solicitar ni conceder autorización para presentar reclamaciones o peticiones colectivas»».

${ }^{30}$ Artículo 182: «Cualquier opción política o sindical de las que tienen cabida en el orden constitucional será respetada por los componentes de los Ejércitos. El militar deberá mantener su neutralidad no participando en actividades políticas o sindicales, ni tolerando aquellas que se refieren al ejercicio o divulgación de opciones concretas de partidos o grupos políticos o sindicales, dentro de los recintos militares. No podrá estar afiliado o colaborar en ningún tipo de organización política o sindical, asistir a sus reuniones ni expresar públicamente opiniones sobre ellas. Los militares no profesionales, durante el tiempo de prestación de su servicio en las Fuerzas Armadas, podrán mantener la afiliación que con anterioridad tuvieran, pero se abstendrán de realizar actividades políticas o sindicales». 
profesión. Aseveración que se ejemplifica en los gravosos requisitos que se imponían a los Oficiales que decidieran seguir sirviendo a su país desde otro sector de la cosa pública ${ }^{31}$.

Sobre esta regulación han existido abundantes debates no exentos de polémica. Debates que han llegado hasta casi la actualidad, dado que el nuevo estatuto jurídico de los militares no llegó hasta el año 2011. No se descubre el Mediterráneo si se dice que todos ellos tuvieron que ver, de un modo u otro, con la repercusión jurídica que supuso la entrada en vigor de la Constitución. Esta afectaba, formal y materialmente, al régimen de derechos y libertades en general y, consecuentemente, al de los miembros de las FAS. Para algunos autores, aquélla debía ser la «correa de transmisión» que condujera a que los derechos fueran regulados adecuadamente ${ }^{32}$.

Una de esas polémicas ya fue apuntada al poco tiempo de aprobarse las Reales Ordenanzas vía ley ordinaria. Se dijo -y se siguió diciendo hasta fechas bastante cercanas- que las exigencias de los artículos 53 y $81.1 \mathrm{CE}$ obligaban a regular la materia por ley orgánica, donde se respetase en todo caso el contenido esencial de cada uno de los derechos en liza ${ }^{33}$. Otra de ellas se interrogaba y se interroga sobre el posible efecto negativo que tales restricciones podían acabar produciendo entre los militares, haciéndoles refractarios a un sistema, el democrático, que nunca verían como propio porque este no les daba realmente cabida ${ }^{34}$.

31 Artículo 211: «Todo militar que acepte ser designado para el desempeño de una función pública, se presente a elecciones para órganos representativos o participe de cualquier otro modo en la dirección de los asuntos públicos, pasará a la situación que señale la Ley, que determinará los efectos que por tal causa se deriven para su carrera».

32 Así opinaban, entre otros, Morales Villanueva, A., «Derechos y libertades del militar profesional», Revista de Estudios Políticos, núm. 37, 1984, pp. 89-109; y MARTíNEZ MARTínez, S., «Limitación a los derechos fundamentales de la Constitución en relación con las Fuerzas Armadas», en Ramírez JimÉnez, M. (ed.), LóPEz RAMÓN, F. (dir.), FERnÁndez López, J. (coord.)., La Función Militar en el Actual Ordenamiento Constitucional Español, op. cit., pp. 603-616; y GuATtA MARTORELL, A., «Los derechos fundamentales de los militares», en Gómez Ferrer-Morant, R. (coord.), Libro Homenaje al Profesor José Luis Villar Palasi, Civitas, Madrid, 1989, p. 581.

33 En ese sentido, véase Martínez Martínez, S., «Limitación a los derechos fundamentales de la Constitución en relación con las Fuerzas Armadas», op. cit. pp. 605 y ss; MartíneZ MartíneZ, R., «Las Reales Ordenanzas. ¿Una norma inconstitucional?», en RAMíREZ JimÉnez, M. (ed.)., López RAMÓn, F (dir.); FERnÁNDEZ LóPEZ, J (coord.)., La Función Militar en el Actual Ordenamiento Constitucional Español, op. cit., pp. 501-512; Blanco Valdés, R., La Ordenación Constitucional de la Defensa, Tecnos, Madrid, 1988, p. 92 y ss; Blanquer Criado, D., Ciudadano y Soldado. La Constitución y el Servicio Militar, Civitas, Madrid, 1996, p. 500 y ss; y Presno Linera, M.A., «Los límites de los límites a los derechos fundamentales de los militares», op. cit, pássim.

34 Vid. Buiza CoRTÉs, T., «Los militares y el derecho de participación política», en Prieto, L. y Bruquetas, C. (eds.), Libertades Públicas y Fuerzas Armadas, Ministerio de 
Aunque las dudas no son pocas, todos los autores son plenamente conscientes -especialmente los que pertenecen a la carrera de las armas, aunque no sólo- que un Ejército no funcionaría si no se preservan algunos valores básicos intrínsecamente unidos a la institución, tales como la jerarquía, la disciplina, la unidad y -cuestión que nos interesa especialmente- la neutralidad política ${ }^{35}$. Al lector no se le escapará que el necesario correlato de dicha visión es la restricción de los diferentes derechos fundamentales de los militares ${ }^{36}$. Se abría así una de las principales líneas de investigación que ha concitado la atención normativa, jurisprudencial y doctrinal, como es la que intenta dar respuesta a la siguiente pregunta: ¿cómo conseguir conjugar tales valores castrenses con la normatividad y eficacia de una Constitución tan preocupada por hacer realidad los derechos fundamentales?

\subsection{El marco jurídico actual: La Ley Orgánica 9/2011, de 27 de julio, de derechos y deberes de los miembros de las Fuerzas Armadas}

Ese nuevo régimen al que aludíamos antes no se basa en postulados diferentes. La norma de 2011 también se preocupa por intentar conjugar los valores y bienes en juego a los que se acaba de hacer referencia. Veamos.

Ya en el Preámbulo el legislador dirá que «(...) los miembros de las Fuerzas Armadas gozan de los derechos fundamentales y libertades públicas de aplicación general a todos los ciudadanos y las limitaciones para su ejercicio deben ser proporcionadas y respetuosas con su contenido esencial. [Las limitaciones] se deben establecer con el objetivo de que las Fuerzas Armadas, manteniendo sus características de disciplina, jerarquía y unidad y el princi-

Educación y Ciencia-Instituto de Derechos Humanos de la Universidad Complutense de Madrid, Madrid, 1986, pp. 369-389; y Casado Burbano, P., «La Despolitización de los Militares Profesionales en la España Democrática», op. cit., p. 15.

${ }^{35}$ Sobre el contenido y exigencias de los dos primeros puede verse Nevado-Batalla Moreno, P., «Singularidades y perspectivas sobre el régimen disciplinario militar», Documentos de Seguridad y Defensa, núm. 34, 2010, CESEDEN, Madrid, pp. 47-55. Desde una perspectiva puramente castrense, algunos autores sostienen que, en la actualidad, tales valores se cumplen en el Ejército español. Vid. MuÑoz-Grandes GaliLEA, A., «Los Ejércitos ante la crisis. Capacidad de adaptación, firmeza de valores», Discurso pronunciado en la Real Academia de Ciencias Morales y Políticas, 9 de abril de 2013 (se puede ver aquí: $<$ http://www.racmyp.es/intervenciones/INTERVENCIONES.CFM? $i=1460 \& t=2>$. Consultado el 2 de mayo de 2014).

${ }^{36}$ Desde una perspectiva aperturista, por todos, véase Presno Linera, M.A., «Los límites de los límites a los derechos fundamentales de los militares», op. cit., p. 71 y ss. Desde una posición marcadamente institucional, así lo observa FERNÁNDEZ-FLORES, J.L., «Los fundamentos del orden jurídico militar en el estado social y democrático de derecho», en Prieto, L. y Bruquetas, C. (eds.), op. cit., p. 267 y ss. 
pio de neutralidad, estén en condiciones de responder a las exigencias en el ámbito de la seguridad y la defensa nacional (...)».

Esto supone dos cosas, que aun obvias merecen ser recordadas. Por un lado, que nuestros soldados son titulares de los derechos fundamentales que la Constitución establece (va de suyo que en los términos que esta establezca). Por otro, que tales derechos, y en concreto los derechos políticos, se verán seriamente limitados para salvaguardar la eficacia de los Ejércitos en los ámbitos de acción que les son propios ${ }^{37}$.

A la hora de establecer dicho estatuto jurídico, el legislador creyó oportuno establecer como pórtico el principio de neutralidad política y sindical. Este se concreta, de nuevo, en una prohibición lindando con lo absoluto: en lo que aquí interesa, significa que al militar se le impide fundar y/o afiliarse a partidos políticos, debiendo observar una estricta neutralidad pública para con toda actividad que los mismos realicen ${ }^{38}$.

Dicho postulado atraviesa las libertades señaladas, hasta el punto de que los límites establecidos al efecto se han visto reforzados. La libertad de expresión es buen ejemplo de ello, puesto que queda sometida a las necesidades

37 Artículo 1: «Esta ley orgánica regula el ejercicio por los miembros de las Fuerzas Armadas de los derechos fundamentales y libertades públicas establecidos en la Constitución, con las peculiaridades derivadas de su estatuto y condición de militar y de las exigencias de la seguridad y defensa nacional (...)». Artículo 3: «Los miembros de las Fuerzas Armadas son titulares de los derechos fundamentales y libertades públicas reconocidos en la Constitución, sin otros límites en su ejercicio que los establecidos en la propia Constitución, en las disposiciones que la desarrollan, en esta ley orgánica y en las leyes orgánicas penales y disciplinarias militares».

38 Artículo 7: «1. El militar está sujeto al deber de neutralidad política. No podrá fundar ni afiliarse a partidos políticos y mantendrá una estricta neutralidad pública en relación con la actuación de los partidos políticos. 2. El militar no podrá ejercer el derecho de sindicación y, en consecuencia, no podrá fundar ni afiliarse a sindicatos ni realizar actividades sindicales. Tampoco permitirá su ejercicio en el ámbito de las Fuerzas Armadas, salvo las que para el personal civil se contemplan en la Ley Orgánica 11/1985, de 2 de agosto, de Libertad Sindical y demás legislación aplicable. En todo caso mantendrá su neutralidad en relación con la actuación de los sindicatos. Los miembros de las Fuerzas Armadas no podrán recurrir a los medios propios de la acción sindical, entendida como negociación colectiva, adopción de medidas de conflicto colectivo y ejercicio del derecho de huelga. Tampoco podrán realizar acciones sustitutivas o similares a este derecho, ni aquellas otras concertadas con el fin de alterar el normal funcionamiento de las unidades de las Fuerzas Armadas». Es importante acotar qué encierra tal deber, tal y ha podido verse en la polémica sobre la imposibilidad de que los militares participen en las elecciones primarias del PSOE. Aunque reconociendo que quizá es un «no problema», el profesor FLORES entendía que tal concurso, en caso de haberse producido, no habría cuestionado el principio de neutralidad política por, entre otros motivos, no ser estrictamente un acto de colaboración con dicha formación. Vid. FLORES, F., «¿Pueden los militares votar en las primarias?», Al Revés y al Derecho, 26 de marzo de 2014 (<http://alrevesyalderecho.infolibre.es/?tag=primarias $>$. Consultado el 20 de abril de 2014). 
impuestas por la salvaguarda de la seguridad y defensa nacional, el deber de respeto, así como debido a la dignidad de personas, instituciones y poderes públicos. Aun es más: se hace valer el principio de neutralidad cuando el militar esté ejerciendo su derecho a expresarse libremente, por cuanto se le veda formular cualquier tipo de pronunciamiento público referente a partidos y asociaciones políticas, así como respecto a cargos públicos, consultas y procesos electorales, referendos y similares. Por si ello fuera poco, y cuando se trate de asuntos relacionados con el servicio, el ejercicio de este derecho queda supeditado a lo que imponga la disciplina militar ${ }^{39}$.

El derecho de reunión se ha regulado de forma similar a como se venía haciendo ${ }^{40}$; esto es, sin mucho margen de acción para el soldado. Así, en principio goza de este derecho conforme aparece regulado en la legislación específica. Pero deberá tener en cuenta que no podrá acudir a reuniones o manifestaciones de carácter político (o sindical), ni tampoco vestir el uniforme o emplear su condición de militar para participar en cualesquiera actos públicos de corte político. Retomando el espíritu y la letra de normas pasadas, toda reunión a celebrar en dependencia militar deberá contar con autorización expresa y previa del jefe de turno, aunque en este caso se añade que podrá denegarlas motivando tal decisión en aras de proteger ciertos bienes en juego ${ }^{41}$.

${ }^{39}$ Artículo 12: «1. El militar tiene derecho a la libertad de expresión y a comunicar y recibir libremente información en los términos establecidos en la Constitución, sin otros límites que los derivados de la salvaguarda de la seguridad y defensa nacional, el deber de reserva y el respeto a la dignidad de las personas y de las instituciones y poderes públicos. 2. En cumplimiento del deber de neutralidad política y sindical, el militar no podrá pronunciarse públicamente ni efectuar propaganda a favor o en contra de los partidos políticos, asociaciones políticas, sindicatos, candidatos a elecciones para cargos públicos, referendos, consultas políticas o programas u opciones políticas. 3. En los asuntos estrictamente relacionados con el servicio en las Fuerzas Armadas, los militares en el ejercicio de la libertad de expresión estarán sujetos a los límites derivados de la disciplina».

40 Vid. Pascua Mateo, F., Fuerzas Armadas y Derechos Políticos, op. cit., p. 284 y ss.

${ }^{41}$ Artículo 13: «1. El militar podrá ejercer el derecho de reunión, de acuerdo con lo previsto en la Ley Orgánica 9/1983, de 15 de julio, reguladora del Derecho de Reunión pero no podrá organizar ni participar activamente en reuniones o manifestaciones de carácter político o sindical. Vistiendo el uniforme o haciendo uso de su condición militar, no podrá organizar, participar ni asistir en lugares de tránsito público a manifestaciones o a reuniones de carácter político, sindical o reivindicativo. 2. Las reuniones que se celebren en las unidades deberán estar previa y expresamente autorizadas por su jefe, que las podrá denegar motivadamente ponderando la salvaguarda de la disciplina y las necesidades del servicio»». Este precepto se aplica al cuerpo de la Guardia Civil por expresa orden legal (Ley 11/2011, de 1 de agosto, para la aplicación a la Guardia Civil del artículo 13.1 de la Ley Orgánica 9/2011), lo que ocasionó que 489 miembros del Cuerpo acudieran al Defensor del Pueblo para que interpusiera recurso de inconstitucionalidad contra la citada disposición por, entre otros motivos, vaciar de contenido el derecho de reunión. La Institución acaba rechazando la petición por entender que la norma permite cierto margen de acción en el ejercicio de aquél. Vid. Defensor Del Pueblo; Informe Anual 2011 y Debates en las Cortes Generales, 
Uno de los principales hitos de la norma que aquí se trae es el reconocimiento del derecho de asociación, con unos márgenes amplios y circunscritos a la normativa específica de desarrollo. Dicha amplitud desaparece si el militar desea asociarse bien para fines políticos bien para fines sindicales, puesto que no se les permite en ninguno de los dos casos; lo mismo sucede si desea vincular tal derecho a partidos políticos y/o sindicatos ${ }^{42}$. Como establece el propio precepto, rige un régimen jurídico específico para las asociaciones militares, dedicando todo un capítulo a su concreción y pormenorización (Título III, Capítulo I, artículos 33-45).

Otras manifestaciones de la libre participación no presentan especiales novedades. Se sigue imposibilitando que el militar sea candidato electoral en tanto en cuanto no esté en la situación legal prevista al efecto ${ }^{43}$. Por lo que hace al derecho de sufragio activo, se conmina a autoridades y mandos a que articulen los medios necesarios para los miembros de las FAS que deseen ejercer esta libertad y por diversas razones (destino, misión, servicio y/o guardia) pudieran verse ocupados en la jornada electoral pertinente ${ }^{44}$. Por último,

Madrid, 2012, pp. 918 y 919 (el documento puede verse aquí: <http://www.defensordelpueblo.es/es/Documentacion/Publicaciones/anual/Documentos/Informe 2011.pdf $>$; consultado el 19 de mayo de 2014). Algún autor también ha creído ver en dicha regulación ciertas trazas de inconstitucionalidad. Vid. GUALDA ALCALÁ, F.J., «La doctrina constitucional sobre el derecho de reunión o manifestación con fines sindicales o reivindicativos: su aplicación a los miembros de las Fuerzas Armadas y la Guardia Civil a la vista de las últimas reformas legales», Revista de Derecho Social, núm. 55, 2011, pp. 151-160.

${ }^{42}$ Artículo 14: «1. Los militares tienen derecho a crear asociaciones y asociarse libremente para la consecución de fines lícitos, de acuerdo con lo previsto en la Ley Orgánica 1/2002, de 22 de marzo, reguladora del Derecho de Asociación. 2. El ejercicio de este derecho cuando tenga como fin la defensa de sus intereses profesionales y los derechos establecidos en esta ley orgánica, se ajustará a lo dispuesto en el título III, capítulo I. 3. Las asociaciones de miembros de las Fuerzas Armadas no podrán llevar a cabo actividades políticas ni sindicales, ni vincularse con partidos políticos o sindicatos». La doctrina ha apuntado que la repercusión de dicho reconocimiento siempre plantea el problema de la sindicación, encubierta o no, de los cuerpos e institutos armados. Si en su momento se permitió el asociacionismo profesional en la Guardia Civil, el siguiente paso podría haber sido el levantamiento del veto para los militares, lo que como se ha visto no ha sucedido. Vid. HeRBÓN COSTAS, J.J., «Sobre el derecho de asociación profesional del militar. ¿Hacia una libertad sindical?», Revista Española de Derecho Militar, núm. 97, 2011, pp. 19-104.

${ }^{43}$ Pasando aquél automáticamente a la situación de servicios especiales, a tenor de la letra del artículo 109.1.d) de la Ley 39/2007, de 19 de noviembre, de la Carrera Militar: «Los militares de carrera y los militares de tropa y marinería con compromiso de larga duración, serán declarados en situación de servicios especiales cuando (...) sean designados como candidatos a elecciones para órganos representativos públicos en ejercicio del derecho de sufragio pasivo o resulten elegidos en las mismas».

${ }_{44}$ Artículo 15: «1. Los miembros de las Fuerzas Armadas tienen derecho de sufragio activo; lo pueden ejercer de conformidad con lo establecido en la legislación sobre régimen electoral general. Las autoridades competentes y los mandos militares establecerán 
algo cabe decir del derecho de petición. La principal preocupación del legislador es que cualesquiera quejas que se deseen hacer llegar al mando deberán respetar unas reglas mínimas, tales como canalizarlas a través del conducto regular-jerárquico o plantearlas de forma respetuosa; ambas exigencias también han tenido su correlato en el desarrollo reglamentario oportuno ${ }^{45}$.

los procedimientos y medios necesarios para facilitar el voto de los militares que se encuentren en cualquier destino y misión, en especial fuera del territorio nacional o cuando estén de servicio o guardia coincidiendo con jornadas electorales. 2. Los militares se encuentran incursos entre las causas de inelegibilidad que impiden el ejercicio del derecho de sufragio pasivo. Para ejercer este derecho deberán solicitar el pase a la situación administrativa prevista, a estos efectos, en la Ley de la carrera militar». Un estudio acerca del voto de los soldados fuera de nuestras fronteras puede verse en GÁlvEZ MuÑoz, L., «El régimen de votación del personal de las Fuerzas Armadas en el exterior», Revista Española de Derecho Militar, núm. 90, 2007, pp. 17-54; de similar tenor es el realizado por Oehling De Los Reyes, A., «Los derechos fundamentales del personal militar embarcado en buque de guerra en misión internacional», Estudios de Deusto, Vol.1, núm. 1, 2012, pp. 233-252.

45 Artículo 16: «El militar podrá ejercer el derecho de petición sólo individualmente, en los supuestos y con las formalidades que señala la Ley Orgánica 4/2001, de 12 de noviembre, reguladora del Derecho de Petición. No son objeto de este derecho aquellas solicitudes, quejas o sugerencias para cuya satisfacción el ordenamiento jurídico establezca un procedimiento específico distinto al determinado en la citada ley orgánica. En el artículo 28 se establecen y regulan las vías para la presentación de iniciativas y quejas en el ámbito de las Fuerzas Armadas». Artículo 28: «1. El militar podrá plantear iniciativas y quejas relativas al régimen de personal y a las condiciones de vida, de acuerdo con lo que se establece en este artículo y en su desarrollo reglamentario, sin perjuicio del mantenimiento del conducto regular. 2. Las iniciativas y propuestas, que afecten con carácter general a los miembros de su categoría, se podrán presentar por cada militar en su unidad ante el oficial, suboficial mayor y cabo mayor designados a tal efecto, quienes las trasladarán al jefe de unidad. El jefe de unidad atenderá y resolverá, en lo que esté en el ámbito de sus competencias, las cuestiones planteadas o las remitirá, con el informe que proceda, al Mando o Jefatura de Personal del Ejército correspondiente. El Mando o Jefatura de Personal acusará recibo, analizará las propuestas en los órganos que se determinen y resolverá, en el ámbito de sus competencias, o las enviará a la Subsecretaría de Defensa. Anualmente se proporcionará información sobre el contenido de las propuestas y el resultado de su estudio. 3. Los miembros de las Fuerzas Armadas podrán presentar quejas relativas al régimen de personal y a las condiciones de vida siguiendo el conducto regular en la estructura jerárquica de las Fuerzas Armadas y haciéndolo de buen modo, verbalmente o por escrito. Si no se considerasen suficientemente atendidas podrán presentarse directamente y por escrito, remitiendo copia al jefe de su unidad, ante los mandos u órganos directivos que se determinen reglamentariamente, los cuales acusarán recibo e iniciarán, en su caso, el procedimiento que corresponda. En caso de rechazar la queja lo harán en escrito motivado. 4. Lo previsto en este artículo será sin perjuicio del ejercicio de los derechos y acciones que legalmente correspondan a los miembros de las Fuerzas Armadas». El desarrollo mencionado se realiza en el Real Decreto 176/2014, de 21 de marzo, por el que se regula el procedimiento para la tramitación de las iniciativas y quejas relativas al régimen de personal y a las condiciones de vida que pueda plantear el militar. 
Llegados a este punto, se debe abordar el examen de lo que ha dicho el principal intérprete jurisdiccional de los derechos que aquí estudiamos (ex artículo 1 LOTC). Ese no es otro que el Tribunal Constitucional, por lo que a las siguientes líneas nos remitimos.

\section{LA JURISPRUDENCIA CONSTITUCIONAL RELATIVA A LOS DERECHOS POLÍTICOS DE LOS MIEMBROS DE LAS FUERZAS ARMADAS}

Lo primero que debe decirse es que el acervo jurisprudencial constitucional no ha sido, ni es a día de hoy, especialmente abundante. La explicación no puede buscarse en otra causa que las severas restricciones antes vistas.

Además, buena parte de las sentencias que se indicarán han sido dictadas conforme a la normativa anterior, aunque si el amable lector ha continuado hasta aquí podrá colegir que, en sus líneas básicas, el marco jurídico no ha sufrido modificaciones de calado, por lo que se entiende que los criterios explicitados allí siguen siendo plenamente operativos en la actualidad. Criterios que confirman que tanto directa como indirectamente, la neutralidad política y las consabidas restricciones a los derechos políticos basados en ella no han sufrido tacha de inconstitucionalidad.

Aunque como obiter dicta, el Tribunal Constitucional ha tenido la oportunidad de recordar que la neutralidad política de los militares es una exigencia que encaja en la Constitución, porque así lo reclaman las misiones constitucionales atribuidas a las FAS en su artículo 8.146. En la STC 101/1991, de 13 de mayo, el Juez de la Constitución sigue una interpretación «finalista y sistemática», mediante la cual «(...) resulta fácil establecer que la finalidad que persigue la LOLS al prohibir la actividad sindical en el interior de los «establecimientos militares» es la preservación de la neutralidad sindical de las Fuerzas Armadas, y así se deduce inmediatamente de las normas que regulan materias conexas dentro de la ordenación jurídica de las mismas, como son el Real Decreto-ley 10/1977, de 8 de febrero y la Ley 85/1978, de 28 de diciembre, aprobatoria de las Reales Ordenanzas de las Fuerzas Armadas, cuyo art. 182 obliga al militar a mantener su neutralidad, no sólo absteniéndose de participar en actividades políticas o sindicales, sino también «no tolerando aquellas que se refieran a grupos políticos o sindicales dentro de los recintos militares». Por tanto, no puede abrigarse duda alguna de que la finalidad de la limitación impuesta por la Disposición adicional tercera de la LOLS se asienta en el citado principio de neutralidad, que a su vez, al igual que otros particulares rasgos organizativos de la institución militar, encuen-

${ }^{46}$ En ese sentido, vid. Pascua Mateo, F., Fuerzas Armadas y Derechos Politicos, op. cit., pp. 144 y 145 . 
tra su justificación en los fines que el art. 8 de la Constitución encomienda a las Fuerzas Armadas» (FJ 4).

Indirectamente, el razonar del $\mathrm{TC}$ al conocer de eventuales violaciones a derechos políticos concretos también permite acoger la neutralidad política como límite. Esto queda reflejado en la jurisprudencia dictada sobre la libertad de expresión y la libertad de asociación, por lo demás las únicas libertades políticas que han llegado al conocimiento del alto tribunal.

\subsection{Jurisprudencia constitucional sobre libertad de expresión}

El principal caso en la materia es el que resuelve la STC 371/1993, de 13 de diciembre ${ }^{47}$. El supuesto de hecho que desencadena el litigio es la publica-

${ }^{47}$ El Tribunal tuvo oportunidad de conocer bien pronto de una petición de amparo por parte de un oficial que había promovido, firmado y contribuido a difundir el llamado «Manifiesto de los Cien». El documento apoyaba sin ambages a los participantes en el Golpe de Estado del 23-F, quejándose amargamente de que estos sufrieran «(...) Ataques, insultos, injurias y calumnias generalizados o directos (...), todos ellos de historial militar brillante e intachable, sobre todo aquellos que por su jerarquía y edad fueron protagonistas de gloriosos hechos de armas, y cuyo valor e integridad profesional no pueden ser puestos en duda por simples conjeturas, sobre todo cuando algunos de ellos están pendientes de la sentencia de un consejo de guerra en cuyo resultado de hechos probados y en la calificación jurídica de estos hechos se determinará la honorabilidad o no de sus conductas (...)». Ante la sanción disciplinaria que se le impuso a dicho mando, confirmada posteriormente en sede judicial, el recurrente aducía haber ejercido su derecho a la libre expresión, libertad reconocida en los artículos 177 y 178 de las Reales Ordenanzas. Así fue como este dictó el ATC 375/1983, de 30 de julio, donde se inadmite a trámite el mismo. Buena parte de la fundamentación jurídica del mismo ha servido posteriormente al TC para abordar casos similares, como ahora se verá. Resumidamente, el Tribunal sostiene que «todo bien o valor constitucionalmente reconocido puede representar, en caso de conflicto, un límite para otros bienes o valores». Además, «dada la importante misión que a las Fuerzas Armadas asigna el art. 8.1 de la C.E., representa un interés de singular relevancia en el orden constitucional el que las mismas se hallen configuradas de modo que sean idóneas y eficaces para el cumplimiento de sus altos fines (...)». Por ello, «la específica naturaleza de la profesión militar exige en su organización un indispensable sistema jerárquico, manifestado en una especial situación de sujeción enmarcada en la disciplina, que impone una precisa vinculación descendente para conseguir la máxima eficacia y el factor de precisa conexión que obliga a todos por igual». Siendo esta disciplina un factor que «indudablemente condiciona el ejercicio por los militares de las libertades públicas realizadas a través de acciones colectivas en determinados supuestos», y entendiendo conforme a la Constitución el régimen jurídico de las peticiones regulado por el artículo 203 de las Reales Ordenanzas (FJ 2. ${ }^{\circ}$ ), analiza la fundamentación desde la óptica del debido respeto a la superioridad. Y no tanto a la militar, sino a quien en nuestro ordenamiento la ostenta porque así lo establece el texto constitucional: las Cortes y el Gobierno. Siendo esto así, el TC dirá que «tal poder representa constitucional y legalmente dicha superioridad de los firmantes, a los que en términos imperativos se hacen llegar propuestas o reclamaciones, pues es indudable que la 
ción de una Carta al Director en el Diario Ya, donde un Teniente Coronel del Arma de Infantería opinaba sobre lo inadecuado del destino de ciertas partidas presupuestarias, mostrándose favorable de afectarlas a necesidades más urgentes. Ante tal publicación, se le sanciona disciplinariamente y, una vez recorrido el periplo contencioso-disciplinario militar y jurisdiccional militar correspondiente sin ver satisfecha su demanda, acciona la vía del amparo ante el TC. Y la Sala Segunda decide denegarlo.

El razonamiento del Tribunal se basa en un principio recurrente en este ámbito. Y es que el ejercicio de este derecho fundamental «está sujeto tanto a límites constitucionalmente expresos, como a otros que puedan fijarse para preservar bienes y derechos constitucionalmente protegidos; si bien, y como precisión necesaria, tampoco podrá atribuirse carácter absoluto a los límites a que ha de someterse el ejercicio de esas libertades: límites que se configuran como excepcionales ante el reconocimiento constitucional del derecho a la libertad de expresión (FJ 2). Y es que es sabido que «hay sectores o grupos de ciudadanos sometidos a límites [en sus derechos fundamentales] específicos, más estrictos, en razón a la función que desempeñan» (FJ 3). A partir de ahí, conecta tales límites con las misiones constitucionales que se atribuyen a las FAS en el artículo $8 \mathrm{CE}$, las cuales requieren «una adecuada y eficaz configuración (...) de la que, entre otras singularidades, deriva su indispensable y específico carácter de organización profundamente jerarquizada, disciplinada y unida (arts. 1 y 10 RR.OO.).

Como consecuencia de ello, y de acuerdo con la doctrina constitucional antes citada, no cabe duda de que el legislador puede introducir determinadas peculiaridades o establecer límites específicos al ejercicio de las libertades reconocidas en la Constitución por los miembros de las Fuerzas Armadas (...)». Y sigue: «el legislador podrá legítimamente imponer límites específicos al ejercicio de la libertad de expresión de los miembros de las Fuerzas Armadas

\footnotetext{
publicidad del escrito pretendió servir de medio -no siendo precisamente el más discreto y respetuoso- para que las ideas y peticiones llegaren a su destino» (FJ 3. ${ }^{\circ}$ ). Habiendo constatado, pues, que la difusión del manifiesto quebró la disciplina exigible, y también la dejación de cumplir para con las obligaciones reglamentarias impuestas, concluye «que no existió en el caso juzgado una manifestación de la libertad de ideas, pensamiento o de expresión que estuviera constitucionalmente permitida» (FJ 4. ${ }^{\circ}$ ). El Tribunal también había dictado anteriormente la STC 51/1989, de 22 de febrero, donde se decidió si ciertas expresiones vertidas en un artículo periodístico respecto al Ejército entraban o no dentro de los márgenes constitucionales de la libre expresión. Sucedía que este -en concreto el Arma de Caballería- era el sujeto pasivo, el que recibió la presunta ofensamientras que el sujeto activo, presunto infractor, no era un militar sino un civil, persona a la que una Audiencia Provincial había condenado a un año de prisión menor por la comisión de un delito de injurias graves; condena que fue confirmada por la Sala Segunda del Tribunal Supremo. El TC acaba por amparar al demandante, constatando que se ha vulnerado su derecho a la libertad de expresión reconocido en el artículo $20 \mathrm{CE}$.
} 
siempre y cuando esos límites respondan a los principios primordiales y los criterios esenciales de organización de la institución militar, que garanticen no sólo la necesaria disciplina y sujeción jerárquica, sino también el principio de unidad interna, que excluye manifestaciones de opinión que pudieran introducir formas indeseables de debate partidista dentro de las Fuerzas Armadas, o, en términos de la STC 97/1985, fundamento jurídico $4 .^{\circ}$ " disensiones y contiendas dentro de las Fuerzas Armadas, las cuales necesitan imperiosamente, para el logro de los altos fines que el art. 8.1 de la C.E. les asigna, una especial e idónea configuración»; todo ello con cierta apoyatura en la jurisprudencia del TEDH del momento, ejemplificada en el caso Engel, de 1976» (FJ 4).

El Tribunal insiste en que «la protección del debido respeto a esos órganos y autoridades resulta un límite legítimo a la libertad de expresión de los miembros de las Fuerzas Armadas, justificado por las exigencias de la específica configuración de éstas, y particularmente como garantía de la necesaria disciplina, entendida tanto en cuanto sujeción a los órganos jerárquicamente superiores, como en cuanto acatamiento y reconocimiento de la superior posición de los órganos encargados de manifestar la voluntad del Estado. No puede entenderse por ello desproporcionada la exigencia de una necesaria mesura más estricta que la exigible de las no pertenecientes a las Fuerzas Armadas (...) en relación con la actuación de órganos constitucionales o autoridades civiles y militares» (FJ 5).

Constatando que los órganos jurisdiccionales han ponderado adecuadamente los bienes constitucionales en juego (FFJJ 6 y 7), deduce que lo que realmente sirvió de base para proceder a sancionar al oficial es «la falta de mesura en la crítica pública formulada (...), que se produjo, tal y como dictaminó el Tribunal Supremo, al haber formulado «juicios de valor en que, de forma abierta e inequívoca, se cuestiona la probidad pública de quienes (Gobierno y Cortes Generales) ejerciendo aquellos poderes, adoptaron la medida» (FJ 8). Por ello, estando ante manifestaciones irrespetuosas para con los órganos constitucionales referidos, y siendo legítimos los límites al derecho a la libre expresión de los miembros de las FAS desde el punto de vista constitucional (FJ 9), se deniega el amparo pedido».

Andando en el tiempo se dictaron dos resoluciones cuyo principal nexo unión fue que la libertad de expresión no era ejercida de forma aislada, sino que aparecía íntimamente ligada a otro derecho fundamental (el derecho a la defensa, reconocido en el artículo $24 \mathrm{CE})^{48}$.

La primera de ellas fue la STC 288/1994, de 27 de diciembre, que traía causa de una presunta vulneración de la libertad de expresión del recurrente,

${ }^{48}$ Hay que hacer notar que la primera y la tercera tienen como sujeto activo a sendos militares, no así la segunda (protagonizada por un policía local). No obstante, las alusiones que el TC hace en aquélla a las Fuerzas Armadas justifica el hecho de que se analicen conjuntamente. 
militar de carrera y experto en Derecho, acaecida en el seno de un recurso de reposición ${ }^{49}$. A través de este, el actor discutía con dureza el nombramiento efectuado por el Ministerio de Defensa para ocupar un alto cargo de la Administración militar, lo que le acaba valiendo sanción disciplinaria por emitir expresiones contrarias al Gobierno. Para el Tribunal Constitucional tuvo una importancia clave que tales manifestaciones se vertieran en el escrito de reposición. El punto de partida de la ratio decidendi es, en buena medida, la resolución arriba comentada. Lo que caracteriza este caso es que las manifestaciones en cuestión se ligan al derecho a impugnar una resolución administrativa, "elemento particularmente trascendente» y que, en cualquier caso, no iban dirigidas a una autoridad militar, sino a un acto dictado por el propio Consejo de Ministros (FJ 2). Preguntándose si la sanción se adecúa a tales parámetros, el TC considera que prevalece «el derecho a exponer los propios argumentos en un procedimiento administrativo»; que la obligación jurídica impuesta a los militares de actuar «con buen modo» no puede ser interpretada «a ultranza de su tenor literal», si con ella se menoscaba tal derecho; y que, además, del análisis de las expresiones que motivaron la sanción se deduce que «es clara la vinculación entre las afirmaciones del actor y los argumentos jurídicos en que basa su tesis»; a lo que debe añadirse que no se aprecia «intento alguno de descalificación del órgano, sino del acto impugnado» (FJ 3$)^{50}$.

La segunda es la STC 102/2001, de 23 de abril. La Sala Primera conoció del caso de un Capitán del Arma de Infantería también sancionado disciplinariamente por realizar manifestaciones de dudosa legalidad. Tales manifestaciones se habían insertado en un recurso de alzada, por lo que el problema se plantea en términos muy similares a los que se acaban de ver. Y, de nuevo, esto será la clave para amparar al recurrente, aunque aquí el Tribunal hace notar una diferencia respecto de aquéllos. Recordando que «la protección del deber de respeto a la superioridad y la correlativa limitación del derecho a la libertad de expresión encuentra especial justificación en exigencias vinculadas a la organización y configuración de las Fuerzas Armadas, y, por ello mismo, han de considerarse constitucionalmente legítimas aquellas restricciones del derecho que sean proporcionadas y obedezcan a motivos necesarios de aseguramiento de la disciplina y de la unidad de acción, imprescindibles para el logro de los objetivos que constitucionalmente se le han encomendado» (FJ 3), observa que «en el presente caso,

${ }^{49}$ Doctrina aplicada expresamente en la STC 120/1996, de 8 de julio, que acaba amparando a un policía local.

${ }^{50}$ Esta línea jurisprudencial debe insertarse en un contexto más amplio, como es el que se dedica al estudio de la libertad de expresión en el marco de procesos jurisdiccionales. A tal fin, véase García NoriegA, A., Libertad de Expresión Forense de los Abogados, Difusión Jurídica, Madrid, 2012. 
a diferencia del decidido por la mencionada STC 288/1994, la impugnación en vía de recurso administrativo se hallaba dirigida contra un acto de la Administración que imponía sanción disciplinaria, y fue ejercitada por militar carente de la condición de Letrado, lo que refuerza en mayor grado, si cabe, la potencialidad del derecho a la defensa en su proyección con el derecho fundamental a la libertad de expresión, íntimamente entrelazados y aquí concernidos» (FJ 4). Trayendo específicamente la resolución dictada en el caso Grigoriades por el TEDH, el TC tiene en cuenta los criterios allí explicitados; esto es, para ponderar si la restricción es jurídicamente legítima o no se deben tener en cuenta criterios adicionales, tales como la «efectiva difusión de las manifestaciones», deduciendo la cobertura del artículo $10 \mathrm{CEDH}$ cuando estas «presenten un insignificante impacto objetivo sobre la disciplina militar» (FJ 5). El Tribunal, aplicando tales cánones, dictamina que la sanción referida vulneró su derecho fundamental a la libertad de expresión, en conexión con el derecho a la defensa, por lo que otorga el amparo $^{51}$.

Finalmente debe hacerse alusión a la STC 272/2006, de 25 de septiembre, que resuelve un amparo solicitado por un miembro de la Guardia Civil al que se le impuso una sanción de un año de suspensión de empleo por la comisión de una falta disciplinaria muy grave. El recurrente impugna tanto las Resoluciones donde se establece dicha sanción como la Sentencia de la Sala Quinta del Tribunal Supremo que desestima su recurso contencioso-disciplinario. Aquél considera vulnerados varios derechos fundamentales. Por lo que ahora interesa, debemos acercarnos a la presunta lesión de la libertad de expresión, en conjunción con la libertad de asociación (artículo $22 \mathrm{CE}$ ) y la libertad sindical (artículo 28.1 CE). El Tribunal recuerda la doctrina constitucional dictada a los efectos -que es la explicitada en sus líneas generales arriba-y

${ }^{51}$ La resolución fue objeto de un Voto Particular por parte del Magistrado D. Fernando Garrido Falla, al que se adhirió el Magistrado D. Manuel Jiménez de Parga, donde se viene a defender un reforzamiento de la disciplina militar. Una vez constatado que los términos literales del recurso son de todo menos adecuados, se plantea que «el problema está en determinar hasta qué punto el derecho de libre expresión en el ejercicio del derecho de defensa constituye argumento suficiente para exonerar de sanción una conducta que, en condiciones normales, es contraria a la disciplina militar y, por tanto, merecedora de ser sancionada». La respuesta que se da es negativa, por diversas razones; aquí, destacaremos una, y es que «las reglas de la disciplina -columna vertebral de la organización militar- no pueden desconocerse so pretexto de que el recurso ordinario es un medio de defensa procedimental y la defensa lo permite todo. A mi juicio, ni la defensa, ni la libertad de expresión; pues una cosa es intentar demostrar la incorrección del acto administrativo que se recurre y otra bien distinta agredir verbalmente o por escrito el autor del dicho acto. La libertad de expresión no puede servir, obviamente, para crear un ámbito exento para actuaciones que el ordenamiento jurídico prohíbe e incluso castiga (delitos de injuria y calumnia)». 
resalta que, en todo caso, a un miembro de las FAS y/o de la Guardia Civil se le debe exigir la mesura necesaria en la manifestación de cualesquiera opiniones. Incluso si este, como era el caso de autos, es representante sindical. El respeto a sus superiores y la preservación del buen funcionamiento del servicio y de la institución policial son, por tanto, límites legítimos de la libre expresión de opiniones y juicios de valor. Interrogándose sobre la ponderación hecha por el órgano jurisdiccional anterior, el Tribunal constata que se ha realizado correctamente, por formular «graves denuncias respecto a diversas cuestiones relacionadas con el funcionamiento interno de la Guardia civil, con el empleo de juicios de valor ciertamente ofensivos hacia los superiores jerárquicos (...). Los juicios vertidos por el recurrente a través de las reseñas periodísticas exceden claramente de la prudencia y mesura con que debe expresarse un miembro de la Guardia civil. Es decir, es la falta de la necesaria mesura en la crítica formulada por el recurrente a la actuación de los mandos de la Guardia civil, y no la crítica misma, lo que justifica la sanción impuesta» $\left(\mathrm{FJ} 9 .^{\circ}\right)$.

\subsection{Jurisprudencia constitucional sobre libertad de asociación}

El otro derecho fundamental que ha merecido la atención directa del Tribunal Constitucional ha sido la libertad de asociación, reconocida en el artículo $22 \mathrm{CE}$. Y la ha merecido tanto para el ámbito de la Guardia Civil como para el ámbito de las Fuerzas Armadas stricto sensu ${ }^{52}$.

Así fue como se dictó la STC 291/1993, de 18 de octubre, resolución que tuvo que conocer del amparo que le solicitaba la Unión Democrática de Guardias Civiles, asociación que había solicitado la pertinente inscripción registral y que obtuvo por respuesta la denegación por silencio administrativo. Ante tal proceder, y sin entrar en el fondo del asunto, el Tribunal Constitucional dictaminó «que la actuación administrativa supuso en este caso una obstaculización enteramente inmotivada del pleno ejercicio del derecho entonces invocado, pues es claro que la libertad de asociación no se realiza plenamente sino cuando se satisface la carga de la inscripción registral que la Constitución impone (art. 22.3) y que la Administración no puede denegar arbitraria o inmotivadamente» (FJ 2). Como quiera que la misma actuó así, entiende el Tribunal que se ha vulnerado la libertad en litigio, procediendo a amparar al recurrente. Así fue como en el apartado $3 .^{\circ}$ del Fallo se ordenó que aquélla quedaba «obligada a dictar una resolución expresa y motivada sobre la procedencia de la inscripción solicitada». Tal obligación se cumplió, denegándose el asiento solicitado ${ }^{53}$.

${ }^{52}$ Vid. Herbón Costas, J.J., «Sobre el derecho de asociación profesional del militar. ¿Hacia una libertad sindical?», op. cit., p. 4 y ss.

53 Vid. Pascua Mateo, F., Fuerzas Armadas y Derechos Politicos, op. cit, p. 380. 
Con todo y con eso, la que parece revestir mayor importancia es la STC 219/2001, de 31 de diciembre. En esta se impugnan una serie de resoluciones administrativas y judiciales que, a juicio del recurrente, habían vulnerado su derecho a la libre asociación. El motivo residía en la negativa a la inscripción en el Registro de Asociaciones de la Hermandad de Personal Militar en Situación Ajena al Servicio Activo, porque se consideró que uno de los fines de la misma ${ }^{54}$ quedaba prohibido por el artículo 181 de las Reales Ordenanzas. El Tribunal, recordando algunos aspectos básicos del régimen del derecho de asociación, acude a la anterior resolución para establecer que no sólo la omisión de respuesta a la petición de inscripción es lesiva para con el derecho de asociación sino que también una denegación «infundada o arbitraria» puede quebrarlo (FJ 5). A partir de ahí constata que el legislador orgánico puede establecer límites al mismo en aras de proteger otros bienes con relevancia constitucional. Pero estos, a su vez, quedan supeditados a cumplir ciertas exigencias formales y materiales. Las importantes para el caso concreto van a ser las segundas, en tanto en cuanto estas deben ser «ciertas y previsibles», amén de resultar proporcionadas y respetuosas para con el contenido esencial de aquél. Aplicadas pues al presente caso, el TC observó que no habían sido respetadas. El quid de la cuestión pasaba por las resoluciones impugnadas. Y estas, sobre todo las judiciales, habían encauzado el caso como un ejercicio encubierto del derecho a la sindicación, vedado para los militares conforme al artículo 1.3 de la Ley Orgánica 11/1985, de Libertad Sindical. Al creer que el artículo 3 c) de los Estatutos de la Hermandad pretendía llevar a cabo «actividades reivindicativas», y estando estas también prohibidas para los militares en el precepto antes aludido, la consecuencia que ambas resoluciones estimaron conforme a Derecho era dictaminar que la administración había actuado correctamente. Tal y como dice el TC, «nada permite afirmar que una asociación, por el hecho de perseguir la satisfacción de intereses económicos, sociales o profesionales de sus asociados, se convierta en un sindicato o pueda ser equiparado al mismo a los efectos del art. 28.1 CE. Ello supone, en primer lugar, una indebida restricción del derecho de asociación, por aplicación de un criterio contrario al principio de interpretación de la legalidad en el sentido más favorable a la efectividad de los derechos fundamentales, reiteradamente reconocido por este Tribunal (STC 146/1999, de 27 de julio, FJ 6). Y supone también una indebida extensión, a los expresados efectos, del concepto de sindicato, al desconocer, de hecho, otros rasgos que lo caracterizan, tanto histórica como legalmente» (FJ 10). A mayores, «la Hermandad no pretendió en ningún momento su reconocimiento como sindicato»; «de los fines estatutarios no se deduce que la Hermandad se constituya en

${ }^{54}$ Según el artículo 3.c) de los Estatutos, la asociación tenía como uno de sus fines «realizar las gestiones precisas para conseguir para sus miembros cuantos beneficios sean posibles tanto en el aspecto económico como en el moral o social». 
contrapoder frente a la Administración militar, ni que la Hermandad pretenda -más allá del estricto ámbito subjetivo de sus socios- la defensa o promoción de los intereses propios de los militares.»; y, lo que es definitivo, el artículo 1 de tales Estatutos señalaba que «la Hermandad se constituye sin ánimo de lucro y con renuncia expresa a toda actividad política o sindical» (FJ 11). Razones todas ellas suficientes para que el TC otorgue el amparo ${ }^{55}$.

\section{EL PRINCIPIO DE NEUTRALIDAD POLÍTICA COMO LÍMITE A LOS DERECHOS POLÍTICOS DE LOS MIEMBROS DE LAS FUERZAS ARMADAS}

Llegados hasta aquí, no podemos eludir las razones por las que el estatuto jurídico-político de los militares españoles se configura de tal forma. Aquí vamos a centrarnos en una que destaca por encima del resto. Es la que se refiere al principio de neutralidad política y a las exigencias que este aventura.

\subsection{El deber de neutralidad política como una realidad en el Derecho Comparado}

Los argumentos que suministra el Derecho Comparado sirven de guía orientativa a la hora de abordar la materia; y es conocido que, en la que aquí nos ocupa, cada Estado la ha regulado desde perspectivas puramente idiosincráticas. El comportamiento que los Ejércitos hayan tenido en el pasado, las misiones que sus Constituciones -o normas de inferior nivel- les hayan atribuido y, en suma, lo que esperan las sociedades democráticas de unos militares que se presumen profesionales, son algunos factores que han influido a la hora de determinar qué derechos políticos tienen y hasta qué punto se limita (o no) su ejercicio.

${ }^{55}$ La resolución no sólo es interesante por lo que se acaba de reseñar. El Magistrado D. Julio González Campos evacuó Voto Particular donde se separaba de la mayoría por un único motivo: no elevar al Pleno cuestión de constitucionalidad sobre el artículo 181.1 de las Reales Ordenanzas. A juicio del Juez constitucional, la norma no respetaba los cánones de constitucionalidad del derecho discutido. Formalmente, porque estas ni tenían rango orgánico ni habían sido reiteradas por una norma orgánica posterior. Materialmente, por diversos motivos relacionados con uno sólo y taxativo: la prohibición introducida por dicha norma no tiene fundamento constitucional alguno en el artículo $22 \mathrm{CE}$. Incluso se dirá que la limitación que introduce la misma ni es previsible ni es cierta, incumpliendo así uno de los test a los que el legislador queda sujeto cuando de regular derechos fundamentales se trata. Si a ello se le suma que los destinatarios de la prohibición son definidos genéricamente, el Juez concluye que todo ello conduce a que la Administración pueda interpretar y aplicar extensivamente tal restricción, lo que deviene en «ilegítima» para con el derecho consagrado en aquél. 
En ese sentido se aprecia que, en tanto que la regulación difiere en función del Estado en cuestión, todos o casi todos ellos establecen el deber de guardar neutralidad política ${ }^{56}$. Partiendo de esa base, lo cierto es que las restricciones son de intensidad diferente. Así, se encuentran países que estipulan restricciones altas (caso de Polonia ${ }^{57}$ ); otros donde rigen restricciones moderadas (caso de Italia, Bélgica o Reino Unido, donde los límites operan en gran medida cuando el ciudadano vista el uniforme; o caso de Croacia o Luxemburgo, donde se exige autorización y/o notificación para llevar a cabo actividades políticas); y finalmente, aquellos que han adoptado restricciones leves (Holanda y Alemania, entre otros). Aunque sería complicado incluir a nuestro país de forma definitiva en alguna de las tres categorías, podríamos situarnos, a tenor de lo visto, entre la primera y la segunda ${ }^{58}$.

Aunque desde una filosofía jurídica diferente a la que impera en los sistemas basados en el modelo continental, el modelo de los Estados Unidos de América aporta algunas cuestiones de interés que merece la pena comentar, siquiera brevemente. Su modelo de neutralidad política se plasma en la Directiva del Departamento de Defensa n. ${ }^{\circ} 1344.10$, de 19 de febrero de 2008, sobre Actividades Políticas de los Miembros de las Fuerzas Armadas $^{59}$. Animando a los militares a que desarrollen las «obligaciones propias de la condición de ciudadano», hace una primera distinción importante, dado que los soldados en activo tienen prohibido participar en activi-

${ }^{56}$ Así lo recogen LeIGH, I. y BoRn, H., Handbook on Human Rights and Fundamental Freedoms of Armed Forces Personnel, OSCE-ODIHR, Warsaw, 2008, p. 56 y ss.

${ }^{57}$ El Tribunal Constitucional polaco tuvo que dirimir si la prohibición de afiliarse a un partido político, incardinado dentro del derecho a la participación política, era o no conforme al marco jurídico constitucional e internacional. Y este respondió afirmativamente, haciendo especial hincapié en el principio de neutralidad política, conformado por dos exigencias: la inexistencia de un poder militar autónomo dentro del Estado, capaz de influir en las decisiones políticas, y el apartamiento de las Fuerzas Armadas del área de influencia propia de los partidos políticos. Vid. LeIGH, I. y Born, H., Handbook on Human Rights and Fundamental Freedoms of Armed Forces Personnel, op. cit, pp. 61 y 62. El litigio llegó hasta el Tribunal Europeo de Derechos Humanos que en el caso K.A.B. vs. España, recurso núm. 59819/08, Sentencia del TEDH de 10 de abril de 2012 confirmó el parecer del Juez de la Constitución polaco y declaró que tal medida no atenta contra el artículo $11 \mathrm{CEDH}$. Se verá posteriormente.

${ }^{58}$ Hay autores que sostienen, dicho así o con palabras muy similares, que el estatuto jurídico de nuestros soldados ha sido (y seguiría siendo por lo dicho arriba) de los más restrictivos de toda Europa. Así opinan Martínez Martínez, S., «Limitación a los derechos fundamentales de la Constitución en relación con las Fuerzas Armadas», op. cit., p. 606; y Cotino Hueso, L., El Modelo Constitucional de Fuerzas Armadas, op. cit., pássim.

${ }_{59}$ DoD number 1344.10, February 19, 2008, Political Activities by Members of the Armed Forces. Una interpretación crítica de la misma puede verse en CORBETT, S. y DAVIDSON, M.J., «The Role of the Military in Presidential Politics», Parameters, núm. 10, 2009, p. 58-72. 
dades relacionadas con los partidos políticos («partisan political activity»), prohibición que no rige para los que ya no figuren en dicha situación. Con todo y con eso, a estos últimos se les hace saber que sus actividades políticas no pueden ni deben suponer la concesión de marchamo, patrocinio, o aprobación oficial alguna.

Respecto a qué pueden hacer (apartado 4.1.1), destaca la posibilidad de inscribirse en el censo electoral, votar, y emitir opiniones sobre candidatos y cuestiones políticas (pero no en representación de las Fuerzas Armadas); también se permite que promuevan el ejercicio de tal derecho -el de sufragio activo- siempre que ello no implique usar su autoridad o influencia para interferir en el resultado del proceso electoral correspondiente. Además, pueden militar en asociaciones políticas -estén o no ligadas a partidos políticos- $\mathrm{y}$ acudir a sus reuniones, en tanto en cuanto no vistan el uniforme y respetando las demás restricciones que la norma impone en epígrafes posteriores (ni ejercer cargos en tales asociaciones ni figurar en su lista de patrocinadores, caso de quedar adscritas a las formaciones partidarias). Por lo demás, se les permite firmar peticiones legislativas y electorales a favor de un candidato determinado, siempre que no interfiera en sus obligaciones militares, se haga sin uniforme, y haya sido autorizado previamente por el Secretario de Defensa. Incluso pueden escribir Cartas al Director de cualquier periódico expresando sus opiniones sobre asuntos de interés público y/o político, teniendo en cuenta que no pueden inscribirse en campañas colectivas previamente organizadas ni tampoco pedir el voto a favor o en contra de un partido político, causa partidaria o candidato concreto. Además, si la carta en cuestión la redacta un militar en activo, debe hacer constar expresa y claramente que su visión es estrictamente personal y no la del Departamento de Defensa. A mayores, pueden realizar contribuciones económicas a cualquier organización política, partido o comité, para apoyar a un candidato o a una terna de ellos (respetando las disposiciones vigentes en la materia).

Respecto a lo que no deben hacer los militares en activo (apartado 4.1.2), el nivel de precisión y de detalle -y en ocasiones, de ambigüedad- es digno de mención. Así, el uniforme y la apariencia de apoyatura oficial a la medida en cuestión aparecen recurrentemente como límites. Por ejemplo, a la hora de participar en actividades de recaudación de fondos. Tampoco pueden interferir en ningún proceso electoral, ni publicar ningún tipo de documento ligado a un partido político donde se pida el voto a favor o en contra de un partido o candidato. Las restricciones se van endureciendo: no podrán tomar la palabra en ninguna reunión celebrada por cualquier partido político; ni participar en medio de comunicación alguno en representación de un partido, candidato o defendiendo una causa política determinada. Huelga decir que no se les permite ni acudir ni organizar manifestaciones de partidos políticos, como tampoco pueden ayudar en tareas de transporte a electores a las urnas si dicha asistencia 
está organizada por un partido político. En ese sentido, les queda totalmente vedado acudir de uniforme a cualquier evento que estos organicen.

Resulta llamativo, y creemos que ilustrativo de lo que se dijo arriba, cómo se regula el hecho de mostrar públicamente signos políticos de adhesión. En el apartado del «podrán hacer» se les permite poner en la parte trasera de sus vehículos privados pegatinas con motivos políticos. Pero en el apartado del «no deben» se prohíbe la misma conducta, siempre que sean distintivos de mayor longitud, como carteles o pósters. A mayores, se prohíbe su exhibición en instalaciones castrenses, también si se está en residencias privadas que se encuentren en su interior.

Y no menos llamativo resulta el hecho de que todas las restricciones extractadas no operan -o no con tanta intensidad- en el caso de que el militar decida enrolarse en actividades políticas a nivel local (siempre que no estén auspiciadas por un partido político concreto). En tal caso, se permite su implicación en tales acciones siempre que lo realice en el marco establecido por aquéllas (por ejemplo, no llevar uniforme, ni usar instalaciones gubernamentales para tal fin, ni intentar hacer pasar por apoyo institucional lo que es mera iniciativa privada).

Otra muestra de la importancia de la cuestión es la Guía que todo Oficial tiene, donde se establece el Código Ético para sus tropas. En esta, cabe leer párrafos como el que sigue: «Mantente fuera de la política. No te enredes con la política. La actividad política es contraria a la tradición militar americana. Como ciudadano, gozas del derecho a tener tus opiniones y el deber de votar, pero guárdatelas para ti, para casa o para el grupo de amigos. Puedes hacerlo sin que ello suponga una castración intelectual. También recuerda que criticar al Presidente es especialmente inapropiado dado que, al fin y al cabo, es el Comandante en Jefe de las Fuerzas Armadas ${ }^{60}$.

Una aproximación indiciaria respecto al balance que se hace de la regulación parte de diferentes enfoques. Quienes observan en esta un esquema a tener muy en cuenta a la hora de exportarlo a otras latitudes les parece que se puede hablar de un modelo de éxito ${ }^{61}$. Quienes pertenecieron en otra época a las Fuerzas Armadas Norteamericanas lo critican por insuficiente. En concreto, porque no sólo no asegura el principio de neutralidad política, sino que tolera y ampara su quiebra ${ }^{62}$.

${ }^{60}$ El texto se traduce del original recogido por DzENEVs, I., «Limits of Civil Rights as a Guaranty of Political Neutrality», Foreign Military Studies Office, Fort Leavenworth (Kansas), 2013, p. 5 (texto consultado el 21 de mayo de 2014 aquí: <http://fmso.leavenworth.army.mil/>).

${ }^{61}$ Así, ibídem, p. 4 y ss.

${ }^{62}$ Vid. Corbett, S. y Davidson, M.J., «The Role of the Military in Presidential Politics», op. cit., p. 64 y ss. Debe hacerse notar que los autores centran su estudio sobre todo en la participación de algunos oficiales retirados, no en el militar en activo. 


\subsection{El deber de neutralidad política como límite permitido por la legislación internacional}

Efectivamente, someter al deber de neutralidad a los militares de los diferentes Estados no parece ir en contra de los Tratados Internacionales que obligan a España ${ }^{63}$. La principal norma en la materia es el Pacto Internacional de los Derechos Civiles y Políticos. Y esta reconoce el derecho a la libre expresión (artículo 19); el derecho a la libre reunión (artículo 21); el derecho a la libre asociación (artículo 22); y el derecho a la libre participación política (artículo 25). Todos ellos tienen límites muy similares en su ejercicio: la protección de otros bienes tales como la seguridad nacional, la seguridad pública o el orden público. Además, la libre asociación puede soportar restricciones específicas en su ejercicio cuando se trate de miembros de las Fuerzas Armadas y de la Policía (quizá porque se regula junto al derecho de sindicación ${ }^{64}$. Si las Fuerzas Armadas del país en cuestión tienen asegurado proteger tales bienes, la legitimidad de eventuales limitaciones se hace más clara $^{65}$. Pero si estas no tienen atribuido tales cometidos, habría que hacer algún matiz ${ }^{66}$. En este supuesto, los límites que se establezcan a sus derechos deberán soportar un escrutinio más severo, siendo excepcionales y quedando sometidos, en todo caso y como mínimo, al principio de legalidad ${ }^{67}$.

A nivel regional, no se puede dejar de lado el impacto que ha tenido tanto el CEDH como el TEDH. En aquél se reconocen los derechos políticos referidos y, a su vez, los presupuestos necesarios para su eventual limitación;

${ }^{63}$ Véase Fernández SEgAdo, F., «Las restricciones de los derechos de los militares desde la perspectiva del ordenamiento internacional», Revista de Estudios Politicos, núm. 64, 1989, pp. 93-130; PeÑarrubia IZA, J.Mª., Presupuestos Constitucionales de la Función Militar, op. cit., p. 101 y ss; y PASCUA MATEO, F; Fuerzas Armadas y Derechos Politicos, op. cit, p. 45 y ss.

${ }^{64}$ Vid. LeIGH, I. y Born, H., Handbook on Human Rights and Fundamental Freedoms of Armed Forces Personnel, op. cit., p. 65 y ss.

${ }^{65}$ Un caso paradigmático es el de Turquía, donde parecen pesar restricciones absolutas al ejercicio de este tipo de derechos. Vid. Corrales Elizondo, A., «Consideración sobre un posible estatuto general de derechos y obligaciones del militar profesional en el marco de la ley 17/1999, de 18 de mayo», en VV.AA., III Jornadas sobre asesoramiento jurídico en el ámbito de la Defensa. Normativa reguladora del militar profesional en el inicio del siglo XXI y otros estudios jurídicos militares, Ministerio de Defensa, Madrid, 2001, p. 27.

${ }^{66}$ Es sabido que nuestras Fuerzas Armadas (ya desde hace muchos años) no llevan a cabo tal cometido, el cual queda reservado para las Fuerzas y Cuerpos de Seguridad del Estado. Vid. Cotino Hueso; El Modelo Constitucional de Fuerzas Armadas, op. cit., p. 398 y ss; y FernÁndez SEgAdo, F., «El estatuto jurídico-constitucional de las Fuerzas Armadas y su desarrollo legislativo. Balance de un cuarto de siglo», Revista Española de Derecho Constitucional, núm. 70, 2004, p. 190 y ss.

${ }^{67}$ Así lo defiende PeÑarrubia IzA, J.Mª ., Presupuestos Constitucionales de la Función Militar, op. cit, p. 103. 
presupuestos que, por lo demás, guardan similitud con los que enuncia el Pacto. De esa forma el derecho a la libre expresión se reconoce en el artículo 10 (derecho que, según reza su apartado 2, «podrá ser sometido a ciertas formalidades, condiciones, restricciones o sanciones previstas por la ley, que constituyan medidas necesarias, en una sociedad democrática, para la seguridad nacional, la integridad territorial o la seguridad pública, la defensa del orden y la prevención del delito, la protección de la salud o de la moral, la protección de la reputación o de los derechos ajenos, para impedir la divulgación de informaciones confidenciales o para garantizar la autoridad y la imparcialidad del poder judicial»); y el derecho a la libre reunión y asociación -y sindicación- se reconoce específicamente en el artículo 11 (donde en su apartado 2 recoge y amplía, específicamente, las posibilidades de restringir tales derechos para los soldados, cuando dice que: «El presente artículo no prohíbe que se impongan restricciones legítimas al ejercicio de estos derechos para los miembros de las Fuerzas Armadas, de la Policía o de la Administración del Estado») ${ }^{68}$.

Como ya se ha dicho, el TEDH ha dictado algunas sentencias donde aborda frontalmente la problemática del ejercicio de derechos políticos por parte de miembros de las Fuerzas Armadas de los Estados parte. Partiendo de la base de que algunos sectores doctrinales ya han estudiado con detenimiento la cuestión, aquí sólo se pretende dar cierta continuidad en el tiempo a esa línea ${ }^{69}$.

En ese sentido, destacan algunas resoluciones que vienen a confirmar las argumentaciones que el TEDH siguió allá por la década de los setenta en la sentencia sobre el caso Engel (STEDH de 8 de junio de 1976). Como es sabido, algunos militares de reemplazo alegaron la vulneración de tres derechos políticos, la libre expresión y la libre reunión y la libre asociación. El TEDH consideró que en realidad sólo el primero de ellos era el que realmente estaba en juego (párrafo 107), por lo que a él dedicó su atención primordial. El Tribunal no dudaba de que la sanción impuesta constituyera una injerencia en tal derecho, por lo que la cuestión residía en conocer si esta cumplía con los cá-

${ }^{68}$ Lo más parecido a una regulación de las libertades de participación política aparece en el artículo 3 del Protocolo 1 al CEDH que reza así: «Las Altas Partes Contratantes se comprometen a organizar, a intervalos razonables, elecciones libres con escrutinio secreto, en condiciones que garanticen la libre expresión de la opinión del pueblo en la elección del cuerpo legislativo». Una exégesis del precepto puede verse en GARCíA RocA, J., «Del compromiso de los Estados de organizar elecciones libres al derecho de sufragio de los ciudadanos», en García Roca, J. y Santolaya Machetti, P., La Europa de los Derechos. El Convenio Europeo de Derechos Humanos, Madrid, 2009 (2 edición), pp. 897-927.

69 Vid. Pascua Mateo, F., Fuerzas Armadas y Derechos Políticos, op. cit., p. 50 y ss; y Peñarrubia Iza, J.Mª ., Presupuestos Constitucionales de la Función Militar, op. cit., p.106 y ss. 
nones exigidos por el CEDH. Y respondió afirmativamente. Lo hizo comenzando por recordar que la medida estaba prevista por la ley (párrafo 96), y que era necesaria en una sociedad democrática para la defensa del orden (párrafos 98-102). En ellos dejó argumentos a tener en cuenta. Así, para el TEDH el orden público también incluía el orden «que debe reinar en el interior de un grupo social concreto (...), especialmente cuando, como en el caso de las Fuerzas Armadas, el desorden de este grupo puede incidir sobre el orden de la sociedad entera» (párrafo 98). Siendo claro «que la libertad de expresión garantizada por el artículo 10 es aplicable a los militares (...)», no lo es menos «que el funcionamiento eficaz de un ejército difícilmente se concibe sin reglas jurídicas destinadas a impedir que sea minada la disciplina militar, particularmente mediante escritos (...) no pudiendo olvidar ni «las características peculiares de la vida militar», ni «los específicos deberes y responsabilidades de los miembros de las Fuerzas Armadas» (párrafo 100). Todo ello condujo a que el TEDH no observara la quiebra de la libertad aducida ${ }^{70}$.

Esto ha quedado directamente rubricado en el caso Joksas contra Lituania, decidido por STEDH de 12 de noviembre de 2013, también sobre la posible vulneración de la libertad de expresión de un militar. La principal polémica se presentaba al coincidir en el tiempo la finalización de la prestación de servicios con un artículo de prensa en el que el oficial criticaba la nueva ley disciplinaria militar. El Tribunal vuelve a recordar algunos criterios que ya parecen jurisprudencia más que consolidada - «El artículo 10 no se para a la puerta de los cuarteles. Se aplica a los militares del mismo modo que se aplica al resto de personas bajo la jurisdicción de los Estados Parte. Ello no impide, tal y como el Tribunal ha indicado previamente, que el Estado establezca restricciones a la libertad de expresión si existe una amenaza real a la disciplina militar, dado que un correcto funcionamiento del Ejército es difícilmente imaginable sin prescripciones legales diseñadas para prevenir su menoscabo por parte de los soldados. Sea como fuere, ello no permite a las autoridades nacionales que, basándose en las mismas, se frustre toda expresión de opiniones, incluso si estas se dirigen contra las Fuerzas Armadas como institución» (párrafo 70); no obstante, el Tribunal considera que aquélla no se lesionó dado que al demandante no se le impuso ningún tipo de sanción al hilo de dicho artículo (párrafo 70), sino que la finalización en la prestación de servicios aconteció por haber alcanzado la edad legal establecida al efecto (párrafo 71).

El TEDH muestra ciertos titubeos cuando pone dicha decisión en un marco secuencial que, ante los claroscuros que presentaba, a buen seguro influyó

${ }^{70}$ Lo que no significa que el TEDH no apreciara la vulneración de otros preceptos (como finalmente hizo respecto a los artículos 5.1 y $6.1 \mathrm{CEDH}$ ). El litigio en general fue sumamente polémico, llegando a evacuarse hasta ocho opiniones disidentes por otros tantos Jueces. 
en acabar reconociendo la vulneración del derecho reconocido en el artículo 6.1 CEDH (donde se reconoce el derecho a un juicio equitativo). Así, dirá que: «El Tribunal constata que, a pesar de que la secuencia de eventos -las críticas vertidas por el demandante en el Kano Diena, la investigación interna de sus acciones, la sanción disciplinaria por no recabar el consejo legal pertinente e, incluso, la decisión de licenciarle por su edad-podría dar la razón a la versión del demandante, ello no permite al Tribunal concluir con certeza que este fuera sancionado por sus opiniones y no por la mera aplicación del artículo 38.1.7 de la LMS. En anteriores casos, el Tribunal ha observado que la sanción disciplinaria por manifestar opiniones en público, así como el juicio y condena de un soldado han operado como indicadores claros, interfiriendo en el derecho de comunicar ideas reconocido en el artículo 10 del Convenio. En este caso, tales indicadores están ausentes. Ninguno de sus superiores jerárquicos hizo declaraciones públicas en el sentido de que hubiera que apartarle por sus opiniones (...)»; (párrafo 72).

Indirectamente, estos criterios también se han dejado sentir en fechas próximas. Primero, en el caso Strzelecki contra Polonia, decidido por STEDH de 10 de abril de 2012 (sobre una presunta vulneración del derecho de asociación en su vertiente de afiliación a un partido político), que continuaba el periplo judicial que la Sentencia de su Tribunal Constitucional parecía haber resuelto en el año 2002. El demandante, un policía local, consideró que la legislación polaca que prohibía la afiliación a partidos políticos lesionaba su derecho de asociación, reconocido en el Convenio en los términos arriba indicados. El Tribunal, recordando que «el artículo 11 en su párrafo 2 autoriza expressis verbis a los Estados a imponer restricciones legítimas a la libertad de asociación de miembros de sus fuerzas armadas, de su policía o de su administración» (párrafo 40), somete la restricción al conocido test: saber si tal restricción está prevista por la ley y persigue un fin legítimo y necesario en el marco de una sociedad democrática (párrafo 42). Lo realmente interesante es cómo razona sobre las dos últimas exigencias, porque se entienden de aplicación a los Ejércitos. Y es que, para el TEDH, «esta medida trata de garantizar la neutralidad política y la imparcialidad de los agentes de la policía municipal, y de preservar la confianza legítima de los ciudadanos en este cuerpo de funcionarios. Se trata de valores indispensables para el cumplimiento eficaz de la misión (...) en materia de protección del orden público, de la seguridad y de los derechos y libertades de los ciudadanos. (...) La prohibición en causa trata de impedir en este cuerpo de funcionarios la influencia directa de los partidos políticos y garantizar que su eficacia no padezca la eventual corrosión de la neutralidad política de algunos agentes. El Tribunal estima que la voluntad de preservar una función pública imparcial, políticamente neutra y ajena al combate político constituye una finalidad legítima en una sociedad democrática. Confirma la opinión del Tribunal Constitucional polaco según la cual el hecho de autorizar la implicación de los 
agentes concernidos en las actividades de los partidos políticos podría desembocar en la importación al seno de este cuerpo de funcionarios de los conflictos políticos y sobre su instrumentalización en beneficio de intereses partidistas y selectivos. Dicha situación constituiría un obstáculo a la eficacia y a la disponibilidad de dicho cuerpo de funcionarios, perjudicial al interés del Estado y de los ciudadanos» (párrafo 44).

Aun aceptando algo de raigambre histórica para con este tipo de limitaciones, y aun reconociendo que el legislador podría en un futuro suprimirlas si ese fuera su deseo (párrafo 45), lo cierto es que la misma es plenamente vigente, dado que no puede discutirse el margen de apreciación nacional existente en la materia (párrafo 49) ${ }^{71}$.

Recordando el contenido del apartado 2 del artículo 11 antes citado (párrafo 50), de nuevo aparece el margen de apreciación nacional «en materia de reglamentación del estatuto y las condiciones de carrera de los agentes del Estado que participan directamente en el ejercicio del poder público y en las funciones que tratan de proteger los intereses generales del Estado» (párrafo 51). De nuevo apoyándose en la jurisdicción constitucional patria, señala que «(...) el Tribunal Constitucional polaco, en su sentencia, insistió en el hecho de que la neutralidad política de las personas que pertenecen a la función pública era un valor que prima sobre su libertad de asociación (...). La importancia de ciertos cuerpos de funcionarios para el buen funcionamiento de una sociedad democrática hacía necesario asegurar su neutralidad política mediante medidas como la prohibición de afiliación a partidos políticos. Dicha medida, destinada a garantizar la separación requerida entre el cuerpo de funcionarios encargados de la aplicación de la Ley y los partidos o agrupaciones políticas, trataba de prevenir el eventual conflicto de intereses susceptible de producirse en caso de pertenencia de dichos agentes a un partido político paralelamente al ejercicio de sus funciones. La eventual implicación de los agentes en los conflictos sectarios, en consecuencia de su afiliación a partidos políticos, podía perjudicar la estabilidad, la objetividad y la continuidad del servicio público, en detrimento del interés del Estado y de los ciudadanos» (párrafo 53). Teniendo en cuenta, además, que el alcance de la restricción es limitado, por cuanto la legislación polaca prevé «que éstos conservan el derecho a expresar sus opiniones y preferencias políticas bajo otras formas diferentes a la afiliación a un partido político (...), no parece que esta medida tenga por vocación prohibir la eventual implicación de los agentes concernidos en la actividad política; solo se aplica a las actividades susceptibles de implicar una real posibilidad para ellos de influir sobre el poder

${ }^{71}$ Sobre tal categoría verse GARCíA RocA, J., El Margen de Apreciación Nacional en la Interpretación del Convenio Europeo de Derechos Humanos: Soberanía e Integración, Civitas-Instituto de Derecho Parlamentario, Madrid, 2010. 
y la política del Estado» (párrafo 57). Y así es como decide que el límite basado en la neutralidad política no atenta contra el artículo $11 \mathrm{CEDH}^{72}$.

También se enjuició el caso Szima contra Hungría, decidido por STEDH de 9 de octubre de 2012 (sobre una presunta vulneración del derecho a la libertad de expresión). Al publicar una serie de opiniones polémicas en la web del sindicato, a la demandante -veterana policía y líder de una importante central sindical- se la sanciona por insubordinación. El pleito llega hasta Estrasburgo, donde alegará que se ha vulnerado su derecho a la libertad de expresión en relación con su derecho al libre ejercicio de la actividad sindical. Pero el Tribunal no está de acuerdo con dicha aseveración. Recuerda este su doctrina sobre la libertad de expresión en general y también sobre la que específicamente rige para las Fuerzas Armadas y cuerpos policiales. Así, el TEDH llega a la conclusión de que se cumplen todas las exigencias del test de constitucionalidad europeo. Primero, porque la medida está prevista por el Código Penal. Segundo, porque establecer límites específicos al ejercicio de los derechos para garantizar la disciplina inherente a esos cuerpos es un fin que se antoja necesario en una sociedad democrática (párrafo 25).

El Tribunal consideró que se cumplía, además, el requisito de la «necesidad social imperiosa». Y lo argumenta así: «El Tribunal observa que, en algunos documentos publicados en la página web (...) la demandante planteó cuestiones laborales, tales como remuneraciones pendientes de pago, que afectaban a los militares, incluyendo a los miembros del sindicato (...). Sin embargo, también criticó la forma en la que los líderes de la policía manejaban las fuerzas del or-

${ }^{72}$ El Juez Thor Björgvinsson emitió opinión concordante, donde dijo haber votado «(...) con grandes dudas la no violación del Convenio en el presente asunto. Como señala el apartado 45 de la sentencia, el Tribunal Constitucional polaco juzgó que las restricciones en litigio podían justificarse por consideraciones debidas del pasado comunista del país. Estimando que éstas continúan siendo pertinentes en Polonia, nuestro Tribunal admite que las restricciones en litigio son importantes para preservar la confianza legítima de los ciudadanos en el Estado y sus instituciones. Me parece un poco raro que el Tribunal Constitucional polaco haya estimado que Polonia se encontraba todavía, en cierta manera, en un período transitorio más de doce años después del hundimiento del sistema comunista. Por tanto, no soy capaz de rechazar esta opinión. Después de todo, el Tribunal Constitucional está mejor situado que un Juez internacional para valorar la necesidad de las restricciones en causa a la luz de la situación actual. Sin embargo, pienso que las limitaciones impuestas al derecho del demandante a adherirse a un partido político solo pueden justificarse teniendo en cuenta este contexto histórico y transitorio. Fuera de este período excepcional de transición, ningún argumento puede, en mi opinión, legitimar la imposición de una prohibición definitiva a adherirse a un partido político a personas que se encuentran en la misma situación que el demandante. Es por ello que suscribo la opinión formulada por el Juez Fischbach en su opinión disidente adjunta a la Sentencia Rekvényi contra Hungría (TEDH 1999, 23), según la cual «(...) las malas experiencias del régimen comunista deberían incitar a los responsables políticos a cambiar de pedagogía con el fin de consolidar el proceso democrático y de preparar el futuro para un espíritu de apertura y tolerancia»»». 
den, y los acusó de faltar al respeto a los ciudadanos y de servir a los intereses políticos en general (...). Para el Tribunal, estos últimos pronunciamientos, sobrepasan el mandato de un dirigente sindical, porque en absoluto está relacionado con la protección de los intereses laborales de los sindicalistas. Por tanto, dichas declaraciones, se han realizado fuera del ámbito legítimo de las actividades sindicales, y deben ser consideradas desde la perspectiva de la libertad de expresión en general más que desde el punto de vista particular de las expresiones sindicales. Recordando el artículo 11.2 CEDH, dirá que «las restricciones impuestas a los tres grupos mencionados deben interpretarse estrictamente y por tanto deben limitarse al «ejercicio» de los derechos en cuestión, es decir, estas restricciones no deben comprometer la esencia misma del derecho a sindicarse (...). Por ello, «el Tribunal aplicará el mismo criterio en el contexto del artículo $10 \mathrm{y}$ hace hincapié en que el derecho a la libertad de expresión pertenece a todos, incluidos los miembros de las Fuerzas Armadas» (párrafo 31).

De ese modo, «[e]1 Tribunal comparte la opinión de los tribunales nacionales respecto a la naturaleza de las opiniones expresadas acerca de la práctica de la gestión policial. Se admite que esas acusaciones -en particular las que acusan la gestión de los altos cargos de policía, de orientación política e intenciones ocultas, rebeliones, falta de profesionalidad y nepotismo- eran de hecho, aunque representasen juicios de valor, capaces de causar insubordinación, ya que podrían desacreditar la legitimidad del funcionamiento de la policía, más todavía desde que la demandante no aportó ninguna base fáctica para aclarar esas declaraciones (...). La demandante, como un jefe de policía, tiene una influencia considerable sobre los sindicalistas y otros militares, entre otras cosas, mediante el control de la página web del sindicato. Como un oficial de alto rango y líder sindical, la demandante debería haber ejercido su derecho a la libertad de expresión de conformidad con las obligaciones y responsabilidades que este derecho lleva consigo en las circunstancias específicas de su situación y en vista de la especial necesidad de disciplina en las fuerzas del orden (...) -y esto incluso enfrentando el interés general adjunto de permitir la crítica como la transparencia, profesionalismo y respeto a la Ley dentro de las fuerzas del orden. El Tribunal observa que, al entrar en la policía, la demandante debería haber sido consciente de las limitaciones que se aplican a los funcionarios en el ejercicio de sus derechos. Teniendo en cuenta el margen de apreciación aplicable a estos casos (...) el mantenimiento de la disciplina sancionando opiniones acusatorias que debiliten su confianza y la credibilidad de la dirección de policía, representa una «necesidad social imperiosa», y los motivos citados por las autoridades nacionales para justificarlo, son pertinentes y suficientes (...) especialmente en vista de la sanción relativamente leve impuesta a la demandante (...)» (párrafo 32$)^{73}$.

${ }^{73}$ El Juez Tulkens, a la sazón Presidente del Tribunal, evacuó una opinión disidente que induce a la reflexión. Los motivos gravitaban en torno a lo que consideraba una vul- 


\subsection{El deber de neutralidad política como una exigencia derivada de las funciones atribuidas a las Fuerzas Armadas}

Hasta ahora se ha visto cómo los derechos políticos de los militares han sido tradicionalmente limitados, sobre todo, para garantizar la jerarquía y disciplina inherente a las Fuerzas Armadas. Y también se ha visto que ello ha tenido su rúbrica legislativa y su convalidación jurisprudencial, tanto en instancias nacionales como internacionales. Creemos que existen algunas razones desde la óptica interna para que el principio de neutralidad política se incluya dentro de dicho acervo ${ }^{74}$.

Lo primero que debe hacerse notar es que dicha asepsia no sólo opera como consecuencia directa de la «estricta subordinación [de las Fuerzas Armadas] a la sociedad a la que sirven» -que lo hace, sin duda- sino como algo, si cabe, más importante; bien mirada nuestra reciente Historia puede que el mantenimiento de dicha neutralidad fuera el principal factor que garantizó la transición militar en España, motivo que supuso un «éxito de proporciones históricas en un país con una larga y abundosa tradición de golpes, pronunciamientos y militaradas varias $\rangle^{75}$.

La importancia del postulado queda acreditada, también, al observar que es una variable de la mayor importancia, dado que sirve para indagar acerca de la democraticidad del sistema ${ }^{76}$; operación que se realiza teniendo en

neración del artículo 10 CEDH. Y dirá: «Tanto el derecho a la libertad de expresión garantizado en el artículo 10.1 del Convenio, como las limitaciones y restricciones previstas en el artículo 10.2, deben aplicarse de la misma manera y con el mismo rigor. A este respecto, teniendo en cuenta las cuestiones planteadas en este caso, soy incapaz de encontrar qué medidas adoptadas contra la demandante eran proporcionales al fin perseguido» (apartado 3). Además, critica el criterio mayoritario por eludir la vertiente sindical del caso para centrarse exclusivamente en la libertad de expresión (apartado 4), así como por reconocer que a la demandante se la prohibió en sede nacional aportar pruebas, para luego decir que «en sus ataques sobre las actividades de la dirección de la Policía, la demandante no pudo relacionar sus ofensivos juicios de valor a los hechos» (apartado 5). Finalmente, reflexiona sobre la propia medida punitiva, defendiendo que mientras «que la sanción puede ser considerada como leve, no se puede decirse lo mismo con la degradación, que en mi opinión es una sanción severa, y en el contexto del presente caso, desproporcionada» (apartado 6).

${ }^{74}$ En ese sentido, vid. Casado Burbano, P., «La Despolitización de los Militares Profesionales en la España Democrática», op. cit., p. 5; Mozo SeOANE, A., «Reflexiones sobre los derechos y deberes del militar profesional», op. cit. y CORRALES Elizondo, A., «Consideración sobre un posible estatuto general de derechos y obligaciones del militar profesional en el marco de la ley 17/1999, de 18 de mayo», op. cit., p. 20 y ss.

75 Así lo dice Requena y Díaz de Revenga, M., «Transición militar y valoración pública», Claves de Razón Práctica, núm. 229, 2013, p. 22.

${ }^{76}$ Operación que de alguna manera ya había llevado a cabo FINER, estudiando comparadamente el nivel de cultura política. Lo que vino a demostrar el politólogo británico era que allí donde este era escaso la intervención política de los Ejércitos era mucho más 
cuenta, a su vez, si las Fuerzas Armadas del país de turno tienen poco o mucho peso en el ámbito político ${ }^{77}$. Y algunas investigaciones muestran que, para alcanzar el objetivo - para conocer si estamos ante una democracia homologable como tal- aquéllas deben abandonar cualquier vestigio o reducto de poder político (siendo el militarismo algo sospechoso) ${ }^{78}$. De lo que se deduce que el éxito en el aseguramiento de la neutralidad política ha tenido como feliz consecuencia para España la más que buena salud democrática de sus $\mathrm{FAS}^{79}$.

Pero es que, además, existen algunas disposiciones desde la propia Constitución que sirven de apoyo a la tesis referida. Si las Fuerzas Armadas que se recogen en el artículo $8 \mathrm{CE}$ se integran en la Administración General del

probable que en aquellos lugares donde este era elevado. Vid. FinER, S.E., The Man On Horseback. The Role of the Military in Politics, Penguin Books, Harmondsworth, Middlesex, 1976, p. 77 y ss.

77 Variable que, siguiendo a Martínez, estaría integrada, entre otros factores, por el apartidismo, y por la limitación de determinados derechos y libertades públicas. Vid. MARTínez, R., «Nuevos tiempos para las Fuerzas Armadas en democracia y nuevos perfiles de sus componentes», Working Paper, núm. 321, Institut de Ciències Politiques y Socials-Universitat Autónoma de Barcelona, Barcelona, 2013, p. 7 (<http://www.icps. cat/archivos/Workingpapers/wp321.pdf>. Acceso: 7 de mayo de 2014). Egipto es un preocupante ejemplo de lo que se quiere decir. El Ejército golpista que depuso al Presidente Morsi dirigió el proceso que desembocó en una nueva Constitución para el país (votada en referéndum con una participación del 38.6\% y un $98.1 \%$ de «síes»). Algunos artículos de la misma abren la puerta a ese Ejército tutelar que ha sido ampliamente superado en latitudes democráticas; y, por ello, a la posibilidad de convertirse de facto en el auténtico y supremo árbitro político del sistema. Primero, dado que el artículo 201 obliga a que el Ministro de Defensa -Comandante en Jefe de estas, sólo por debajo del Presidente de la República- sea un Oficial; y el artículo 234 establece que durante ocho años - dos mandatos presidenciales- la persona que lo ocupe deberá obtener el plácet del Consejo Superior de las Fuerzas Armadas. Segundo, debido a que el artículo 203 crea y regula un Consejo Nacional de la Defensa que tiene atribuida responsabilidad exclusiva sobre el presupuesto de Defensa (controlando así el 35\% del PIB patrio). Y tercero, porque el artículo 204 extiende la jurisdicción penal militar a los civiles en diversos y difusos supuestos. Un ejemplar de la Constitución aludida, en traducción no oficial, puede verse aquí: <http://www.sis.gov.eg/Newvr/Dustor-en001.pdf $>$ (consultado el 18 de junio de 2014). El diagnóstico parece claro: estamos ante un «Estado administrado por los militares», según el criterio de GóMEZ GARCíA, L., «Egipto, represión y Constitución», El País, 28 de diciembre de 2013 (el texto se ha leído el 19 de junio aquí:<http://elpais. com/elpais/2013/12/19/opinion/1387448357_772808.html>).

78 Véase López Ramón, F., La Caracterización Jurídica de las Fuerzas Armadas, Centro de Estudios Constitucionales, op. cit, p. 7 y ss. Entendiendo por militarismo aquélla «tendencia ideológica que pretende implantar usos, estilos, leyes o costumbres militares en la vida política de una nación». Esa es la definición que da Puell De LA Villa, F., Historia del Ejército en España, Alianza Editorial, Madrid, 2005, p. 291.

79 MARTínEZ, R., «Nuevos tiempos para las Fuerzas Armadas en democracia y nuevos perfiles de sus componentes»op. cit, p. 6 y ss. 
Estado (aun con las peculiaridades que le son propias) ${ }^{80}$, se les debe exigir que cumplan con los cometidos constitucionales atribuidos respetando las exigencias derivadas de tal afirmación ${ }^{81}$. Ello supone conectar, al menos, los artículos 8, 97 y $103 \mathrm{CE}$, concluyendo que la eficacia y la neutralidad -el tercer precepto habla de «imparcialidad» ${ }^{82}-$ serán criterios del todo punto exigibles a la hora de realizar las funciones asignadas. Funciones que queda-

${ }^{80}$ Se está haciendo referencia al que quizá sea el debate más longevo y que atraviesa toda la materia: el de la naturaleza jurídica de las Fuerzas Armadas. Es bien sabido que las posturas son básicamente dos, con una tercera que podría decirse ecléctica. La primera es la que defiende que aquéllas son una Institución, lo que implica que lo militar, en general, es y debe ser diferente a lo civil; por ello, los valores intrínsecos al oficio deben primar por encima de cualquier otra consideración (jerarquía y disciplina, básicamente), limitándose el Derecho «general» a recordarlo, y dejando para el Derecho «específico» (militar) la regulación de tales extremos. No obstante, también debe hacerse notar la riqueza de matices que varios autores realizan desde dicha visión Vid. TriLlo-FigueroA, F., «Las Fuerzas Armadas en la Constitución Española. (Esbozo de una construcción institucional)», Revista de Estudios Políticos, núm. 12, 1979, pp. 105-140; LóPEZ GARrido, D., «La Posición Constitucional de las Fuerzas Armadas», Revista de Administración Pública, 1983, núm. 100-102, pp. 949-971; FERNÁNDEZ-FLORES, J.L., «Los fundamentos del orden jurídico militar en el estado social y democrático de derecho», op. cit., pp. 263-274; y FERNÁNDEZ SEGAdO, F., «La Posición Constitucional de las Fuerzas Armadas», Revista Española de Derecho Militar, núm. 67, 1996, pp. 13-71. Recientemente, puede verse LóPEZ MEDEL, J., «El Ejército como institución. Análisis del artículo 8 CE», Revista Española de Derecho Militar, núm. 99, 2012, pp. 373-391. Del otro lado, varios autores defienden que las Fuerzas Armadas son una Administración Pública, por lo que quedan integradas como cualquier otra en el marco del ordenamiento jurídico general (aunque muchos de estos autores son conscientes de la importancia de los valores aludidos para un correcto funcionamiento de aquéllas). Representantes de esta línea serían GuAITA, A., «La Administración Militar», Revista de Administración Pública, núm. 7, 1952, pp. 105-126; LÓPEZ RAMÓN, F., La Caracterización Jurídica de las Fuerzas Armadas, op. cit., pp. 316 y ss; Blanco Valdés, R., La Ordenación Constitucional de la Defensa, op. cit., p. 64 y ss; Mozo Seonne, A., «Las Fuerzas Armadas y su Ordenamiento Jurídico (Una relectura del debate sobre el artículo 8 de la Constitución)», Revista Española de Derecho Militar, núm. 65, 1995, pp. 609-629; también BlanQuer Criado, D., Ciudadano y Soldado. La Constitución y el Servicio Militar, op. cit., p. 233 y ss; Cotino Hueso, L., El Modelo Constitucional de Fuerzas Armadas, op. cit., pássim; y Pascua Mateo, F., Fuerzas Armadas y Derechos Políticos, op. cit., p. 35 y ss. Posturas más o menos eclécticas podrían ser la de Herrero de MiÑón, M., «Tareas Constitucionales de las Fuerzas Armadas: entre el Interés Nacional y la Supranacionalidad», Discurso pronunciado en la Real Academia de Ciencias Morales y Políticas, 12 de diciembre de 2000 (consultado aquí: <http://www. racmyp.es/publicaciones/discursos.cfm >, el 10 de mayo de 2014); y la de LóPEZ DE GEA, J., «El Estatuto Jurídico de las Fuerzas Armadas», Revista de Derecho-UNED, núm. 12, 2013, pp. 397 y ss.

${ }^{81}$ Por todos, véase LóPez Ramón, F; La Caracterización Jurídica de las Fuerzas Armadas, Centro de Estudios Constitucionales, op. cit., pássim.

82 Vid. Peñarrubia Iza, J.M. ${ }^{\text {a }}$, Presupuestos Constitucionales de la Función Militar, op. cit., p. 152. 
rán incardinadas en la Defensa Nacional, categoría que a su vez «trasciende y desborda, tanto desde el punto de vista orgánico como material a las $\mathrm{FAS})^{83}$.

Tales principios influyen en el cumplimiento de las misiones constitucionales, independientemente de que el margen de decisión de las Fuerzas Armadas en torno a las mismas sea inexistente (que parece que lo es ${ }^{84}$ ). El Gobierno de la Nación, como órgano constitucional de la mayor relevancia, tiene atribuida la dirección de la política interior y exterior, así como la Administración civil y militar (ex artículo $97 \mathrm{CE})^{85}$. Una mayor implicación militar en la vida política puede generar una mayor tentación de cuestionar las órdenes gubernamentales que -repárese en esto- provienen del exacto cumplimiento de lo que unas (pero también) las otras exigen ${ }^{86}$. Es decir, que

${ }^{83}$ Tomamos las palabras de Mozo Seonne, A., «Las Fuerzas Armadas y su Ordenamiento Jurídico (Una relectura del debate sobre el artículo 8 de la Constitución)», op. cit., p. 626. Esto significa, con otras palabras, que nuestros Ejércitos ni son ni pueden ser actores políticos autónomos que decidan el qué, el cómo y/o el cuándo de su puesta en marcha. Pero todavía existen voces que se oponen a ello. Se alude al General de División (r.), D. Juan Antonio Chicharro, quien se despachó públicamente con aseveraciones tales como que «la patria es anterior y más importante que la democracia», o que «el patriotismo es un sentimiento y la Constitución no es más que una ley». Eso bastaba, a su juicio y conforme a una interpretación nada jurídica del artículo $8 \mathrm{CE}$, para actuar militarmente contra lo que llamó «la ofensiva separatista-secesionista». Los pormenores del incidente quedaron recogidos en los principales periódicos. Véase $<$ http://politica.elpais.com/politica/2013/02/27/actualidad/1361994938_586044.html> (consultado el 19 de junio de 2014).

${ }^{84}$ La mejor doctrina militar y civil viene insistiendo sin ambages en tal extremo. Un representante de la primera ha dicho en ese sentido que «una intervención militar independiente (...) está muy lejos de ser admitida en nuestra doctrina constitucional, hoy, si queremos ser respetuosos con el principio de supremacía civil (...)». Vid. LóPEZ DE GEA, J., «El Estatuto Jurídico de las Fuerzas Armadas», op. cit., p. 394.

${ }_{85}$ Por todos, vid. Blanco Valdés, R., La Ordenación Constitucional de la Defensa, op. cit., pássim.

${ }^{86}$ Da cuenta de ello sin paliativos la LODN. Su artículo 5 recuerda que «corresponde al Gobierno determinar la política de defensa y asegurar su ejecución, así como dirigir la Administración militar (...)». El artículo 6 establece que al Presidente del Gobierno le corresponde «(...) la dirección de la política de defensa y la determinación de sus objetivos, la gestión de las situaciones de crisis que afecten a la defensa y la dirección estratégica de las operaciones militares en caso de uso de la fuerza (...)». Además, «(...) ejerce su autoridad para ordenar, coordinar y dirigir la actuación de las Fuerzas Armadas así como disponer su empleo». También «le corresponde de forma específica (...) formular la Directiva de Defensa Nacional, en la que se establecerán las líneas generales de la política de defensa y las directrices para su desarrollo (...) definir y aprobar los grandes objetivos y planteamientos estratégicos (...)», determinar la aplicación de los objetivos y las líneas básicas de actuación de las Fuerzas Armadas, tanto en el ámbito nacional como en el de la participación en las organizaciones internacionales de las que España forma parte, (...) y ordenar las misiones de las Fuerzas Armadas. Finalmente, el artículo 7 se ocupa de atri- 
los Ejércitos podrían acabar siendo vistos como un actor político más -con todo lo que eso supone ${ }^{87}$ - cuando quizá lo más adecuado sea verle como lo que creemos que son: el brazo armado de un Estado que, en caso de necesidad real y de cumplirse los requisitos jurídicos estipulados al efecto, se acciona a través de quien tiene competencia para ello (fundamentalmente el Ejecutivo ${ }^{88}$.

Valga de ejemplo un caso extremo y esperemos que nunca materializado en el futuro: la declaración del estado de sitio ${ }^{89}$. El juego del artículo 116.4 CE hace descansar en el Gobierno la «propuesta exclusiva» de dicha decla-

buir al Ministro de Defensa, entre otras materias, «(...) el desarrollo y la ejecución de la política de defensa (...), (...) dirigir la actuación de las Fuerzas Armadas bajo autoridad del Presidente del Gobierno (...), y determinar y ejecutar la política militar (...)».

${ }^{87}$ Acudiendo de nuevo al estudio de FINER, la intervención política del Ejército puede revestir cuatro modalidades distintas: la influencia; la presión-chantaje; el desplazamiento (de las autoridades civiles legítimas); y la suplantación (de las autoridades civiles legítimas). A su juicio la primera de ellas sería la única aceptable en un sistema constitucionaldemocrático; o en expresión del autor, la que se realiza siguiendo los «canales constitucionales normales» (aunque advirtiendo que, en ocasiones, las diferencias entre la primera y la segunda categoría son muy difusas). Vid. FInER, S.E., The Man On Horseback. The Role of the Military in Politics, op. cit., p. 127 y ss.

${ }^{88}$ El Parlamento tiene una importancia creciente en estas cuestiones, tal y como muestra el artículo $4 \mathrm{LODN}$, donde se le atribuyen diversas funciones tales como «a) Otorgar las autorizaciones previas para prestar el consentimiento del Estado a obligarse por medio de los tratados y convenios internacionales, así como las restantes autorizaciones previstas en el artículo 94.1.b) de la Constitución; b) Aprobar las leyes relativas a la defensa y los créditos presupuestarios correspondientes; c) Debatir las líneas generales de la política de defensa. A estos efectos, el Gobierno presentará las iniciativas correspondientes, singularmente los planes de reclutamiento y modernización; d) Controlar la acción del Gobierno en materia de defensa; e) Acordar la autorización a que se refiere el artículo 63.3 de la Constitución». Además, «al Congreso de los Diputados le corresponde autorizar, con carácter previo, la participación de las Fuerzas Armadas en misiones fuera del territorio nacional, de acuerdo con lo establecido en esta Ley».

${ }^{89}$ En este terreno se ha desarrollado una corriente doctrinal, quizá mayoritaria, que defiende que para activar a las Fuerzas Armadas a la hora de llevar a cabo cualquiera de las misiones del artículo 8 CE se debería declarar previa e inexcusablemente dicho estado. El sector que parece minoritario es el que sostiene lo contrario; bajo este prisma, el Gobierno quedaría limitado sólo materialmente por la enumeración que realiza el precepto, quedando sólo sujeto, en puridad, a un control netamente político. Vid. LóPEZ RAMÓn, F., La Caracterización Jurídica de las Fuerzas Armadas, Centro de Estudios Constitucionales, op. cit., pp. 324 y 325. Otros autores consideran preferible, para clarificar el asunto, que no se enumeren dichas misiones en la Constitución. Vid. LAFUENTE BALLE, J.Ma ${ }^{\text {, }}$, «Sobre el carácter taxativo o declarativo de la relación de las misiones atribuidas a las Fuerzas Armadas en el artículo 8 de la Constitución», Revista de Derecho Político, núm. 36, 1992, p. 71. Sobre las situaciones de excepcionalidad en general, puede verse FERNÁNDEZ SEgado, F., El Estado de Excepción en el Derecho Constitucional Español, EDERSA, Madrid, 1978; Cruz Villalón, P., Estados Excepcionales y Suspensión de Garan- 
ración, debiendo confirmarla el Congreso de los Diputados mediante mayoría absoluta. Incluso en este supuesto -el que quizá sea el más gravoso, porque estaría en juego la propia supervivencia del país- no existiría margen alguno de decisión para el estamento militar ${ }^{90}$. Para que eso siga siendo así, para preservar que sean los órganos jurídico-políticos los que lleven a cabo sus tareas -que, insistimos, son obligaciones constitucionales y, por ello, sometidas a un riguroso deber de cumplirlas-, se antoja necesario que los militares se preparen para defender el mismo cuando así se les ordene, evitando crear un caldo de cultivo que acabaría por provocar efectos contrarios a los deseados ${ }^{11}$.

Si a ello se le añade que el propio Tribunal Constitucional estableció, expresamente, que esos dos órganos constitucionales -Gobierno y Parlamento- son los superiores jerárquicos de todo soldado (STC 371/1993, de 13 de diciembre, FFJJ 5 y 8); que la neutralidad política es un valor necesario a la hora de afrontar las misiones del artículo 8.1 CE (STC 101/1991, de 13 de mayo, FJ 4); y que, en general, la salvaguarda de otros bienes y valores constitucionales es fundamento bastante para limitar de forma proporcionada los derechos fundamentales de los militares (línea que nace con el ATC 375/1983, de 30 de julio), no parece que la conclusión pueda ser otra que la señalada.

En el otro lado, no cabe desconocer las dudas doctrinales que arrancan del principio de favor libertatis. Por ello, las limitaciones de los derechos políticos sólo deberían ser las necesarias e indispensables en aras de garantizar tales extremos ${ }^{92}$. En ese sentido, algunos autores interpretan que quien debe observar neutralidad es la institución militar como tal, no sus miembros individualmente considerados ${ }^{93}$. La evolución del principio no ha sido escasa y,

tías, Tecnos, Madrid, 1994. También Álvarez García, V., El Concepto de Necesidad en Derecho Público, Civitas, Madrid, 1996.

90 Vid. LóPez Ramón, F., La Caracterización Jurídica de las Fuerzas Armadas, op. cit., p. 326 y ss., y Blanco Valdés, R., La Ordenación Constitucional de la Defensa, op. cit., p. 70 y ss.

${ }_{91} \mathrm{Y}$ es que, en definitiva, el sistema constitucional espera de todo militar que defienda la principal norma de convivencia que nos hemos dado, como es la Constitución (así se establece, verbigracia, en el artículo 5 de LODDMFAS: «El militar guardará y hará guardar la Constitución como norma fundamental del Estado y cumplirá las obligaciones militares derivadas de las misiones establecidas en la Constitución y en la Ley Orgánica 5/2005, de 17 de noviembre, de la Defensa Nacional, con sujeción a las reglas de comportamiento que se definen en esta ley»..

92 Vid. Blanquer Criado, D., Ciudadano y Soldado. La Constitución y el Servicio Militar, op. cit., p. 514 y ss; seguido por PAscua Mateo, F., Fuerzas Armadas y Derechos Políticos, op. cit., p. 144 y ss.

93 Por todos, véase Peñarrubia Iza, J.Ma., Presupuestos Constitucionales de la Función Militar, op. cit., p. 152; y Cotino Hueso, L., El Modelo Constitucional de Fuerzas Armadas, op. cit., p. 385 y ss. Esta línea de pensamiento se observa ya en la obra del profesor Blanquer, quien propuso un símil que ha hecho cierta fortuna en la doctrina. Dirá 
por ello, quizá el futuro vea con menos miedo una apertura del estatuto jurídico-político del militar que en épocas pasadas era impensable (dados los condicionantes por todos conocidos) $)^{94}$. Y se vuelve a recordar lo pernicioso de unas restricciones tan severas porque reproducirían con ello, a la postre, una suerte de acantonamiento que expulsaría al militar de la vida política, creándole la sensación de quedar completamente al margen del sistema ${ }^{95}$.

Por tanto, la cuestión residiría en intentar acotar qué exigencias concretas se derivan de dicha neutralidad; las que caigan dentro de esta permitirían desde la óptica constitucional limitar los derechos políticos de los miembros de las FAS; sensu contrario, aquellas que no fueran una exigencia derivada de garantizar la imparcialidad en el ejercicio de sus funciones no podrían servir como justificación para restringir tales derechos. Así, se ha avanzado una serie de circunstancias objetivas que permitirían conocer si la eventual actividad política del militar compromete o no la aludida neutralidad. Estas serían: el lugar de ejercicio del derecho en cuestión, el momento de su ejercicio, si se despliega de forma individual y/o colectiva, la finalidad y el contenido de dicho ejercicio, si se manifiesta o no la condición militar, y el rango/cargo/empleo ocupado. Aplicadas al caso concreto, servirían para saber si la restricción al derecho en cuestión cumple con los cánones jurídicos al uso» ${ }^{96}$.

Otro criterio que podría sumarse a dicha relación es el que proviene de la diferencia que, desde hace ya lustros, se viene haciendo notar por ciertos sectores doctrinales ${ }^{97}$. Se interpreta que el apoliticismo es una cosa y el apartidismo otra, lo que dejaría la puerta abierta a permitir cierta participación política del militar. La consecuencia de dicha afirmación, que se comparte aquí en sus líneas generales, eleva de dificultad la empresa, porque obligaría

que «(...) la neutralidad es a la política lo que la aconfesionalidad es a la religión. Para que la Administración sea laica no es imprescindible que los funcionarios lo sean (...)». Vid. Blanquer Criado, D; Ciudadano y Soldado. La Constitución y el Servicio Militar, op. cit., p. 515.

94 Vid. Peñarrubia Iza, J.Ma ., Presupuestos Constitucionales de la Función Militar, op. cit., p. 152.

95 Vid. Blanquer Criado, D; Ciudadano y Soldado. La Constitución y el Servicio Militar, op. cit., p. 515 y ss.

96 Vid. Cotino Hueso, L; El Modelo Constitucional de Fuerzas Armadas, op. cit, p. 387.

${ }_{97}$ Uno de los autores más destacados de esta corriente ya dijo en 1984 que «(..) apartidismo no significa apoliticismo. Las Fuerzas Armadas como cualquier otra institución del Estado, deben realizar ante el Gobierno la política que más le convenga para el mejor cumplimiento de la misión que la Constitución le tiene señalada. El apoliticismo del militar es una aberración que le conduce a un vacío intelectual. No podemos olvidar que antes de ser militar, se es ciudadano y como tal, animal político, que debe sentir y vivir las inquietudes de sus semejantes. Por otra parte, la tan traída y llevada integración social del militar no podrá conseguirse si no se siente identificado con los problemas de toda índole que se producen en su país». Vid. Morales VillanueVA, M.A., «Derechos y libertades del militar profesional», op. cit., p. 91. 
al legislador -si así lo estima- a llevar a cabo una labor de selección y despiece para dirimir qué actos individuales serían políticos y qué actos individuales tendrían que ver con la causa partidista ${ }^{98}$.

\section{CONCLUSIÓN}

El régimen jurídico de los derechos políticos de los militares españoles sigue siendo, a la luz de su nuevo marco regulador, sumamente restrictivo. Esto, que tradicionalmente y con carácter general ha obtenido el plácet normativo, jurisprudencial, y doctrinal debido a la necesidad de salvaguardar los principios básicos que estructuran las FAS -jerarquía, disciplina, unidad, y eficacia- también opera respecto a la neutralidad política.

Limitar tales derechos en aras de garantizar la imparcialidad del militar es una técnica ampliamente difundida en otras latitudes que no sólo cabe en el marco jurídico de nuestras obligaciones internacionales, sino que cuando las altas jurisdicciones han tenido que conocer de litigios relacionados con la misma, han aceptado directa e indirectamente su legitimidad y adecuación jurídica. En suma, no parece que se cuestione seriamente lo necesario de la neutralidad política del militar en activo, ni desde el punto de vista político, ni social, ni jurídico.

Justo por todo ello, conviene dedicarle algunos esfuerzos adicionales a la causa para intentar acotar qué exigencias reales plantea. Desde aquí sólo se ha pretendido apuntar algunas razones que conducen a pensar que el diagnóstico aludido no es desacertado. A partir de ahí, se abren algunas posibilidades sugerentes que, a través de la interacción de los diferentes actores en liza, podría ayudar a pulir el status jurídico-político de los miembros de nuestras FAS. A buen seguro que el esfuerzo merecerá la pena para el ordenamiento constitucional en conjunto.

TITLE: The Political Rights of the Armed Forces Members in light of the Political Neutrality Principle.

RESUMEN: El texto pretende estudiar algunas cuestiones relacionadas con los derechos políticos de los militares, a la luz del nuevo régimen jurídico regulado en la Ley Orgánica 9/2011, de 27 de julio, de Derechos y Deberes de los Miembros de las Fuerzas Armadas. Luego de hacer un repaso por la letra de dicha regulación y por la jurisprudencia constitucional en la materia, se reflexionará sobre el principio de neutralidad política

${ }^{98}$ La no intervención en dicha causa es lo que explica que el hecho de ser militar impida competir en cualquier proceso electoral, a tenor del artículo 70.1.e) CE. Así parece interpretar la neutralidad política RoDRÍGUEZ RAMOS, L., «Fundamentos del orden jurídico militar en el estado social y democrático», op. cit., p. 261. 
como un límite adecuado constitucionalmente a la hora de restringir tales derechos.

Palabras ClaVE: Constitución, Derechos Fundamentales, Derechos Politicos, Neutralidad Politica, Fuerzas Armadas.

ABSTRACT: The text aims to study a couple of issues dealing with the political rights of the Spanish Armed Forces members, given the new legal frame settled in the 9/2011 Organic Act. After a brief review of it, and after doing the same thing with the constitutional jurisprudence ruled in the matter, it would be consider how the political neutrality principle is an acceptable constitutional limit when constricting those political rights.

KEYWORDS: Constitution, Fundamental Rights, Political Rights, Political Neutrality, Armed Forces.

RECIBIDO: 21.07.2014

ACEPTADO: 18.11 .2014 